\title{
SIXTH INTERIM STATUS REPORT: MODEL 9975 PCV O-RING FIXTURE LONG-TERM LEAK PERFORMANCE
}

\author{
W. L. Daugherty \\ Savannah River National Laboratory \\ Materials Science \& Technology
}

Publication Date: August 2011

Savannah River Nuclear Solutions

Savannah River Site

Aiken, SC 29808

This document was prepared in conjunction with work accomplished under Contract No. DE-AC09-08SR22470 with the U.S. Department of Energy. 


\section{DISCLAIMER}

This work was prepared under an agreement with and funded by the U.S. Government. Neither the U. S. Government or its employees, nor any of its contractors, subcontractors or their employees, makes any express or implied: 1. warranty or assumes any legal liability for the accuracy, completeness, or for the use or results of such use of any information, product, or process disclosed; or 2. representation that such use or results of such use would not infringe privately owned rights; or 3. endorsement or recommendation of any specifically identified commercial product, process, or service. Any views and opinions of authors expressed in this work do not necessarily state or reflect those of the United States Government, or its contractors, or subcontractors. 


\section{Sixth Interim Status Report: Model 9975 PCV O-Ring Fixture Long-Term Leak Performance}

\section{APPROVALS:}

W. L. Daugherty

Date

Author, Materials Science and Technology

T. E. Skidmore

Date

Technical Review, Materials Science and Technology

K. A. Dunn

Date

Pu Surveillance Program Lead, Materials Science and Technology

G. T. Chandler

Date

Manager, Materials App \& Process Tech

E. R. Hackney

Date

NMM Engineering

REVIEWS:

D. R. Leduc

Date

Savannah River Packaging Technology 


\section{Revision Log}

$\begin{array}{lll}\text { Document No. } & \text { SRNL-TR-2011-00217 Rev. No. } 0\end{array}$

Document Title Sixth Interim Status Report: Model 9975 PCV O-Ring Fixture LongTerm Leak Performance

Rev. \# Page \# Description of Revision Date

$\begin{array}{lll}0 \text { all } & \text { Original document }\end{array}$ 


\section{$\underline{\text { Summary }}$}

A series of experiments to monitor the aging performance of Viton ${ }^{\circledR}$ GLT O-rings used in the Model 9975 package has been ongoing for seven years at the Savannah River National Laboratory. Seventy tests using mock-ups of 9975 Primary Containment Vessels (PCVs) were assembled and heated to temperatures ranging from 200 to $450{ }^{\circ} \mathrm{F}$. They were leak-tested initially and have been tested periodically to determine if they meet the criterion of leak-tightness defined in ANSI standard N14.5-97. Fourteen additional tests were initiated in 2008 with GLT-S O-rings heated to temperatures ranging from 200 to $400{ }^{\circ} \mathrm{F}$.

High temperature aging continues for 33 GLT O-ring fixtures at $200-300{ }^{\circ} \mathrm{F}$. Room temperature leak test failures have been experienced in all of the GLT O-ring fixtures aging at $350{ }^{\circ} \mathrm{F}$ and higher temperatures, and in 7 fixtures aging at $300{ }^{\circ} \mathrm{F}$. No failures have yet been observed in GLT O-ring fixtures aging at $200^{\circ} \mathrm{F}$ for 41-60 months, which is still bounding to Oring temperatures during storage in K-Area Complex (KAC). Based on expectations that the fixtures aging at $200{ }^{\circ} \mathrm{F}$ will remain leak-tight for a significant period yet to come, 2 additional fixtures began aging within the past year at an intermediate temperature of $270{ }^{\circ} \mathrm{F}$, with hopes that they may leak before the $200{ }^{\circ} \mathrm{F}$ fixtures.

High temperature aging continues for 6 GLT-S O-ring fixtures at $200-300{ }^{\circ} \mathrm{F}$. Room temperature leak test failures have been experienced in all 8 of the GLT-S O-ring fixtures aging at 350 and $400{ }^{\circ} \mathrm{F}$. No failures have yet been observed in GLT-S O-ring fixtures aging at 200 $300{ }^{\circ} \mathrm{F}$ for up to 26 months.

For O-ring fixtures that have failed the room temperature leak test and been disassembled, the Orings displayed a compression set ranging from $51-96 \%$. This is greater than seen to date for packages inspected during KAC field surveillance (24\% average).

For GLT O-rings, separate service life estimates have been made based on the O-ring fixture leak test data and based on compression stress relaxation (CSR) data. These two predictive models show reasonable agreement at higher temperatures $\left(350-400{ }^{\circ} \mathrm{F}\right)$. However, at $300{ }^{\circ} \mathrm{F}$, the room temperature leak test failures to date experienced longer aging times than predicted by the CSRbased model. This suggests that extrapolations of the CSR model predictions to temperatures below $300{ }^{\circ} \mathrm{F}$ will provide a conservative prediction of service life relative to the leak rate criterion. Leak test failure data at lower temperatures are needed to verify this apparent trend. Insufficient failure data exist currently to perform a similar comparison for GLT-S O-rings.

Aging and periodic leak testing will continue for the remaining fixtures.

\section{Background}

This is an interim status report for experiments carried out per Task Technical Plans WSRC-TR2003-00325 [1] and SRNS-TR-2008-00054 [2], which are part of the comprehensive 9975 package surveillance program [3].

PCV test fixtures were assembled with either Parker Seals V0835-75 (hereafter referred to as Viton ${ }^{\circledR}$ GLT) O-rings or Parker Seals VM835-75 (hereafter referred to as Viton ${ }^{\circledR}$ GLT-S) O- 
rings, and are being aged in environments that provide varying degrees of margin over KAC storage conditions. The purpose of these experiments is to characterize the performance of the O-ring seals, and then correlate the data to lifetime predictions of PCV and SCV O-ring seals in 9975 packages being stored in KAC. O-ring performance in these tests is defined by leaktightness.

The data from these fixtures are scoping in nature, although most of the controls under which they were collected are typical of baseline data. Accordingly, care should be used to assess the overall quality of the data prior to use in baseline applications. Within the 9975 surveillance program, these data will be used for information only, to compare to baseline data from other testing and build confidence in the overall predictions of O-ring service life.

\section{Experimental Method}

\section{Test Matrix}

Testing has evolved to include 3 test matrices. These address Viton ${ }^{\circledR}$ GLT O-rings aged at 200 or $300{ }^{\circ} \mathrm{F}$, Viton ${ }^{\circledR}$ GLT O-rings aged at $270-450{ }^{\circ} \mathrm{F}$, and Viton ${ }^{\circledR}$ GLT-S O-rings aged at $200-$ $400{ }^{\circ} \mathrm{F}$.

The first test matrix was developed to determine the importance and effect of several variables on the condition of the PCV O-rings over time inside the KAC storage facility. The variables believed to be the most relevant to O-ring performance in storage were O-ring temperature, radiation/dose rate, O-ring lubrication, and internal PCV atmosphere (internal PCV atmosphere was subsequently dropped as a test variable). Two different dose rates were selected to evaluate potential dose rate effects. A total of 62 tests, with 22 separate sets of conditions were developed. Replicates of tests were developed based on a modified full-factorial statistical design. The test variables and the basis for variable selection are given in Table 1.

The interior of the test fixture is accessible through a tube connected to the bottom. This tube includes a $\mathrm{T}$ connection to facilitate leak testing of both O-rings simultaneously or separately. With this arrangement, data is obtained on both O-rings installed in each fixture.

Several fixtures have been removed from the first test matrix since the initiation of the study. Eleven were removed from test based on leak test performance while at their conditioning temperature of $200^{\circ} \mathrm{F}$ or $300^{\circ} \mathrm{F}$ and they were disassembled and examined. Fourteen more were taken out of test after a power failure caused a temperature excursion severe enough to invalidate the tests. One additional fixture was removed from test in 2007 for reasons that were not documented. Fixture 62 was returned to service briefly with new O-rings in 2007, and designated 62-2007. Further details of these fixtures are provided in Reference 4. Several fixtures conditioning at $300{ }^{\circ} \mathrm{F}$ have experienced room temperature O-ring leakage (i.e. failed), beginning in April 2010. The status of each fixture, along with its test parameters, is summarized in Table 2. 
Fixtures in the first test matrix are leak tested on a nominal 6-month schedule. Once the first of these began failing the room temperature leak test, the test frequency for fixtures heated to 300 ${ }^{\circ} \mathrm{F}$ was increased to every 3 months.

In the second test matrix, five fixtures were placed into test in October 2008 with new Viton ${ }^{\circledR}$ GLT O-rings. These fixtures were aged at temperatures ranging from 350 to $450{ }^{\circ} \mathrm{F}$. They were intended to provide some O-ring failures in a shorter time frame to enhance the predictive value of the original test matrix and to determine the time to failure at the "continuous" service temperature rating $\left(400{ }^{\circ} \mathrm{F}\right)$. The predictive model assumes that the time to leakage at all temperatures is a function of a common mechanism. With the expectation that these would fail in a much shorter time than the original fixtures, they have been leak tested on a nominal 3 week frequency.

An additional two fixtures with Viton ${ }^{\circledR}$ GLT O-rings were added to the second test matrix in April 2011, and began aging at $270{ }^{\circ} \mathrm{F}$. With leak test failures experienced at aging temperatures of $300{ }^{\circ} \mathrm{F}$ and above, and no failures projected to occur at $200{ }^{\circ} \mathrm{F}$ for many years yet, it was anticipated that these two intermediate temperature fixtures might experience leak failures sooner that the $200{ }^{\circ} \mathrm{F}$ fixtures. This would provide additional confirmation of the extrapolation model for leak test data at an earlier date than the $200^{\circ} \mathrm{F}$ fixtures.

All of the second matrix fixtures were assembled with the normal O-ring lubricant and contained no backfill gas (i.e. filled with air). Three of them (one each at 350,400 and $450{ }^{\circ} \mathrm{F}$ ) were irradiated to $2 \mathrm{E} 5$ rad at a high dose rate.

The third test matrix repeats much of the variety of the first two matrices with Viton ${ }^{\circledR}$ GLT-S Orings, but on a smaller scale. Seven separate sets of conditions were developed, and tested in duplicate for a total of 14 fixtures. The status of these fixtures, along with their test parameters, is summarized in Table 2.

\section{Initial Assembly and Setup}

The two-piece lid of the mock-up PCV, consisting of the cone seal nut and cone seal plug, was machined to be identical to the actual PCV lid. The body of the mock-up PCV was shortened to 3.5 inches from the original design of 18.6 inches and a threaded hole was machined in the bottom to provide a port for evacuating and filling the vessel with gas and for in-situ leak testing of the O-rings. A PCV test fixture with the O-rings installed in the lid is shown in Figure 1.

The mock-up PCV fixtures were assembled per the requirements described in the 9975 Safety Analysis Report for Packaging (SARP) [5]. After installation of the O-rings and assembly of the mock-up PCV test fixture, an initial leak test was performed while the fixture was at room temperature. If the fixture required irradiation, it was placed in a Co-60 gamma cell and irradiated at one of two dose rates to reach a total dose of $2 \mathrm{E} 5 \mathrm{rad}$. This is equivalent to a ten year dose at the bounding dose rate expected for the PCV O-rings ( $2 \mathrm{rad} / \mathrm{hr}$ ). The fixture was irradiated at either a "slow" dose rate of approximately 667 to $830 \mathrm{rad} / \mathrm{hr}$ or a faster rate of $\sim 1.7 \mathrm{E} 5 \mathrm{rad} / \mathrm{hr}$. After irradiation, the fixture was leak tested again while at room temperature, and heated to test temperature. 
The vessels are heated with a flexible, wound-wire heater wrapped around the vessel circumference. Ceramic fiberboard and fiber batting are used to insulate the exposed ends of the fixtures. Stainless steel tubing is attached to the port on the top of the fixture lid via a highpressure fitting and to the hole machined into the bottom of the PCV body. A thermal fuse was added to each heater to prevent excessive temperature excursions. The heaters are controlled by a desktop computer running LabView ${ }^{\mathrm{TM}}$ software, with feedback via a type-K thermocouple attached to the PCV body. The final assembled fixture is shown in Figure 2.

Initially, there was a plan to raise the temperature of the O-rings in some of the first matrix fixtures to $400{ }^{\circ} \mathrm{F}$ for a half hour period to simulate what might occur during an accident after the O-rings had aged. $400{ }^{\circ} \mathrm{F}$ is the maximum allowable SCV/PCV O-ring temperature for short term conditions [6]. The excursions were initially delayed as a result of the loss of several of the fixtures to disassembly and overheating. Subsequently, estimates of O-ring temperatures in KAC have been revised, with the result that the $300^{\circ} \mathrm{F}$ fixtures already bound a thermal scenario within the facility [7]. Therefore, temperature excursions will not be performed on the O-ring test fixtures.

\section{Fixture Leak Testing}

The O-ring fixtures are leak-tested after initial setup, after irradiation, and periodically thereafter to the same leak-tight criterion as the 9975 PCV and SCV. The outer O-rings of the 9975 PCV and SCV are credited with being leak-tight while in transport and are credited with maintaining containment while in storage in the $\operatorname{KAC}[5,8]$.

A room temperature leakage rate of no more than $1 \mathrm{E}-7 \mathrm{ref} \cdot \mathrm{cc} / \mathrm{sec}$ air $(2 \mathrm{E}-7 \mathrm{cc} / \mathrm{sec} \mathrm{He}$ ) demonstrates leak-tightness when measured according to the requirements outlined in ANSI Standard N14.5-97 [9]. Initially, fixtures were also tested at their conditioning temperature. These additional tests were discontinued, as discussed previously [4].

Leak testing is conducted using a helium mass spectrometer leak detector of the same make and model as that currently used in annual certification testing of the 9975 PCV and SCV, although the method used has been adapted to the O-ring fixtures. A gas filled envelope test, as defined in ANSI N14.5-97 Section A.5.3 is used for the mock-up PCV fixtures. Both O-rings are tested simultaneously, with failure of either O-ring causing a failure of the test. Although this approach differs from annual certification testing, it gives results that are valid and comparable [9], and accommodates the difference in set up of the actual PCV and SCV and the mock-up PCV fixture. If a leak is found, it is possible to determine which O-ring is leaking by selectively directing the helium to either the fixture body or the closure weep hole, thus testing one O-ring at a time.

The O-ring fixture leak test program was reviewed in December 2008, prompting reconsideration of the methodology used for leak testing the mock-up PCV fixtures. One important change that was made in the conduct of the leak test involved extending the test duration until permeation of helium through the O-ring was detected [10]. 
Observing a permeation signal for each test provides positive evidence that the fixture and test setup are capable of transmitting a helium signal (i.e. no part of the flow path is blocked), and that helium was actually introduced into the fixture. Once a permeation signal was observed for each fixture (the permeation response is described in Reference 10), subsequent testing is conducted without the extended duration to demonstrate permeation. All fixtures in test since December 2008 have now demonstrated permeation, as summarized in Table 3. Since the GLTS fixtures began testing in December 2008, they were tested for, and demonstrated, permeation during their baseline testing.

\section{$\underline{\text { Results }}$}

Mock-up PCVs have been assembled and aged in the conductance of 70 tests on GLT O-rings, and 14 tests on GLT-S O-rings. Aging parameters include conditions of temperature, irradiation, and internal gas atmosphere. This report summarizes results for these fixtures through July 1, 2011.

A total of 33 GLT O-ring fixtures (including the two fixtures recently added at $270{ }^{\circ} \mathrm{F}$ ) and 6 GLT-S O-ring fixtures remain in test. All of the GLT O-ring fixtures conditioning at $200{ }^{\circ} \mathrm{F}$ have remained leak-tight at room temperature, with total times at temperature ranging from 41 to 60 months (at the time of their last leak test). Seven of the GLT O-ring fixtures conditioning at $300{ }^{\circ} \mathrm{F}$ have failed to remain leak-tight (in one or both O-rings) at room temperature. Failure of these was identified at exposure times ranging from 34 to 48 months. The other fixtures conditioning at $300{ }^{\circ} \mathrm{F}$ remain in test with exposure times ranging from 48 to 62 months (at the time of their last leak test). Both O-rings in both fixtures aging at $350 \mathrm{~F}$ have failed to remain leak-tight at room temperature, with exposure times ranging from 11 to 20 months. All three GLT O-ring fixtures conditioning at 400 or $450{ }^{\circ} \mathrm{F}$ have failed to remain leak-tight at room temperature and have been removed from service, as reported previously [4]. The times to failure for each GLT O-ring fixture are summarized in Table 4. Detailed leak rate histories can be found in Table 5 for fixtures in test since the last status report [11].

All of the GLT-S O-ring fixtures conditioning at $200{ }^{\circ} \mathrm{F}, 250{ }^{\circ} \mathrm{F}$, and $300{ }^{\circ} \mathrm{F}$ have remained leaktight at room temperature, with total times at temperature of 22 to 26 months. Fixtures conditioned at $350{ }^{\circ} \mathrm{F}$ failed to remain leak-tight at room temperature after a period of 114 and 358 days. Fixtures conditioned at $400^{\circ} \mathrm{F}$ failed after 50-281 days. The times to failure for each GLT-S O-ring fixture are summarized in Table 4. Detailed leak rate histories can be found in Table 5 for fixtures in test since the last status report [11].

Note that $400{ }^{\circ} \mathrm{F}$ is the upper "continuous" service temperature often quoted for O-rings of both Viton ${ }^{\circledR}$ compounds. The basis for such ratings is not well documented by the manufacturer, but thermal ratings are typically based on short-term exposures such as 1000 hours (42 days) exposure [12]. However, seal manufacturers advise that such ratings are generic only and that every design is different. End-users are therefore encouraged to perform specific tests to determine actual service limits. 
Five GLT O-ring fixtures (12, 26, 18D, 19D and 49) conditioning at 300 or $350{ }^{\circ} \mathrm{F}$ in which both O-rings failed were disassembled in March 2011. The following observations were made during disassembly:

- In fixture 18D (350 F), the inner O-ring was tightly adhered to the fixture body and black Oring residue / stain was left on the body (Figure 3). Both O-rings were tightly adherent in the plug grooves and left heavy black stain on both grooves.

- In fixture 19D (350 F), little black stain was left on the fixture body. Both O-rings were tightly adherent in the plug grooves and left heavy black stain on both grooves.

- In fixtures 12 and 26 (300 F), both O-rings were lightly adhered to the fixture body. Limited staining was observed on the fixture 26 body. The inner O-ring was adhered to the plug groove of fixture 26, and light staining was observed on one or both plug grooves of these fixtures.

- The O-rings in fixture 49 were not adherent to the body or plug, and left only light intermittent stain on the plug outer groove.

- $\quad$ Fixture 49 had 2 areas of loose fibers, mostly on the inner O-ring (Figure 4).

- Both O-rings in fixture 49 were observed to be stiffer (harder to stretch) than typical of other aged O-rings.

- Both O-rings in fixture 26 had an intermittent "crease” along the circumference, suggestive of a mold parting line.

All of the O-rings removed during these examinations received dimensional and hardness measurements. Average hardness readings for each O-ring varied from 77 to 81 Durometer M. The hardness of new O-rings is specified as $75+/-5$ Durometer A. While there is no exact conversion between the $\mathrm{A}$ and $\mathrm{M}$ scales, they are generally very similar in value. The hardness increased slightly from baseline measurements for fixtures 12, 26 and 49, and was unchanged for the fixtures 18D and 19D. These differences are not considered significant.

The dimensional measurements were used to calculate compression set. The measurements were taken within 30 minutes of removal, and again after 14 and 30 days. These measurement intervals are generally consistent with that used previously on other fixtures. Most of the relaxation that was seen occurred prior to the second measurement (around 14 days). Compression set results are summarized in Table 6.

\section{$\underline{\text { Discussion }}$}

Each fixture has been tested for permeation. This involves continuing the leak test until the leak rate begins to increase at a continually increasing rate, and is distinguished from a leaking fixture by a time lag between test initiation and the beginning of permeation. In several cases, permeation was not seen initially, and each subsequent leak test repeated the effort until a permeation signal was observed. At this time, all fixtures have shown permeation (Table 3). There is considerable variation in the time to permeate among the fixtures, and among multiple trials for the same fixture. Some tests permeated in as little as 5 minutes, while other tests took up to 75 minutes. There is no apparent trend in this variation. Reasons for the variation are unknown, although limited testing has shown that the amount of vacuum grease on the O-ring can affect permeation performance [10]. 
Extending the leak test to demonstrate a permeation signal provides two functions; it demonstrates an open flow path from the fixture to the detector, and that helium was actually introduced to the fixture. This reduces the chance for false positive results (i.e. leak-tight for reasons other than seal performance). An open flow path has now been demonstrated for all fixtures. In general, they will not be tested to permeation in future leak tests. The test method provides sufficient assurance that helium is provided to each fixture since the bag around the fixture is seen to inflate with helium after it is evacuated.

Compression set values for the O-ring fixtures have been calculated as follows, per ASTM D395 Method B:

$$
\begin{aligned}
& \text { Comp Set }=\left(\text { initial } t_{r}-\text { final } t_{r}\right) /\left(\text { initial } t_{r} \text { - average O-ring groove depth }\right) * 100 \\
& \text { with } t_{r}=\text { radial O-ring thickness }
\end{aligned}
$$

For the GLT and GLT-S O-ring fixtures that were examined following failure of a room temperature leak test, the compression set ranges from 51 to $96 \%$, with an average value of $84 \%$, for measurements within the first 30 minutes. The average compression set was slightly higher for the GLT-S O-rings (89\%) than for the GLT O-rings (81\%). There is a difference between the compression set for GLT O-rings aged at $300-350{ }^{\circ} \mathrm{F}$ (87\% avg) and GLT O-rings aged at 400 $-450{ }^{\circ} \mathrm{F}$ (68\% avg). There is insufficient range in temperature for failed GLT-S O-rings to identify whether a similar trend exists for that compound. However, the GLT-S O-rings exhibit the same compression set at 350 and $400{ }^{\circ} \mathrm{F}$ (89\% avg).

In comparison, the compression set measured on SCV and PCV O-rings during field surveillance to date ranges from -5 to $50 \%$ (with an average of 24\%), following storage periods in KAC of up to 7 years. Some of this variation results from using the assumed initial O-ring thickness of 0.139 inch, since no data exist on the baseline conditions of these O-rings. The average compression set for these O-rings removed from service is significantly less than measured on any O-ring (GLT or GLT-S) which was aged to the point that it did not pass a room temperature leak test.

The compression set data are summarized in Figures 5 and 6 . Figure 5 presents results from measurements taken immediately after opening the vessel (typically within 30 minutes), and includes 2 sets of data from test fixtures with GLT O-rings aged at $300-450{ }^{\circ} \mathrm{F}$. In the first data set, fixtures that failed to remain leak-tight have compression set values of $70-93 \%\left(300{ }^{\circ} \mathrm{F}\right.$ fixtures) or $51-96 \%$ (350 - $450{ }^{\circ} \mathrm{F}$ fixtures). The second set consists of $300{ }^{\circ} \mathrm{F}$ fixtures that were removed from test due to difficulties with high temperature leak testing, but that remained leak-tight at room temperature. These O-rings have compression set values of 75 - 89\%, even though they were at temperature for a much shorter time than the first set. This indicates that a high compression set value is not necessarily an indication of imminent leak failure. In contrast, Figure 5 also shows the compression set data from field surveillance of SCV and PCV O-rings. The field surveillance data show a wide range of scatter due in part to the assumption of an initial nominal O-ring thickness. Nevertheless, the range of compression set data from field surveillance remains consistently at $50 \%$ or less, with time in service ranging up to $\sim 7$ years. Only $1 \%$ of the field surveillance compression set values are greater than $40 \%$, so the typical 
compression set for O-rings in service to date is significantly less than that observed in O-rings which have failed to remain leak-tight. It is currently unknown whether the compression set for O-rings in service will gradually increase to a higher value prior to their failure, but the available evidence strongly indicates the O-rings in service are not close to reaching an end-of-life condition yet.

The compression set data in Figure 6 include results from all fixtures that have failed to remain leak-tight, and show results based on re-measurements taken 26 - 90 days after opening the vessels. By this time, the O-rings have recovered about as much of their original dimensions as is likely. Results for the GLT O-rings appear to fall into separate groupings based on aging temperature, with different behavior at $300{ }^{\circ} \mathrm{F}$ than that at $350{ }^{\circ} \mathrm{F}$ or $400-450{ }^{\circ} \mathrm{F}$. The compression set data for GLT-S O-rings at 350 and $400{ }^{\circ} \mathrm{F}$ are intermediate to the GLT data for these same temperatures.

A separate task $[2,13]$ is underway to correlate the compression stress relaxation (CSR) of Orings with aging temperature. While CSR does not provide a direct correlation to leak tightness, it is hoped that the time for the compressive force to relax to a specific value (such as $90 \%$ or $100 \%$ loss of initial force) may provide a degree of correlation with the service life based on leak-tightness. Lifetime estimates for GLT O-rings based on CSR data have been presented in Reference 14. With several room temperature leak failures of aged O-ring fixtures, an initial comparison is now possible to demonstrate whether CSR data correlates with leak data. This comparison is shown in Figure 7 for GLT O-rings. Lifetime estimates based on the two parameters are similar at higher temperatures $\left(\sim 350-400{ }^{\circ} \mathrm{F}\right)$. Figure 7 also suggests that the CSR data provide a conservative life prediction at lower temperatures with regards to the actual time to leak failure of the O-rings. This observation should be viewed with caution, however, since the lower temperature portions of each curve are based on extrapolation beyond the available data. Insufficient data currently exist to draw a similar comparison for GLT-S O-rings.

\section{Conclusions}

High temperature aging continues for 33 GLT O-ring fixtures at $200-300{ }^{\circ} \mathrm{F}$. Room temperature leak test failures have been experienced in 7 of the GLT O-ring fixtures aging at 300 ${ }^{\circ} \mathrm{F}$, and in all 5 of the GLT O-ring fixtures aging at higher temperatures. No failures have yet been observed in GLT O-ring fixtures aging at $200{ }^{\circ} \mathrm{F}$ for $41-60$ months, which is more representative of (but still bounding to) O-ring temperatures during storage in KAC.

High temperature aging continues for 6 GLT-S O-ring fixtures at $200-300{ }^{\circ} \mathrm{F}$. Room temperature leak test failures have been experienced in all 8 of the GLT-S O-ring fixtures aging at 350 and $400{ }^{\circ} \mathrm{F}$. No failures have yet been observed in GLT-S O-ring fixtures aging at 200 $300{ }^{\circ} \mathrm{F}$ for $22-26$ months.

For GLT O-ring fixtures that have failed the room temperature leak test and been disassembled, the O-rings displayed a compression set ranging from $51-96 \%$. GLT-S O-rings that have been disassembled displayed compression set values of $78-95 \%$. These ranges are higher than seen to date for packages inspected during KAMS field surveillance (24\% average). 
For GLT O-rings at higher temperatures (350 - $\left.400{ }^{\circ} \mathrm{F}\right)$, service life based on the room temperature leak rate criterion is comparable to that predicted by compression stress relaxation (CSR) data. While there are no comparable failure data yet at aging temperatures below $300{ }^{\circ} \mathrm{F}$, extrapolations of the data for GLT O-rings suggests the CSR model predictions provide a conservative prediction of service life relative to the leak rate criterion at KAC storage conditions. Failure data at lower temperatures are needed to verify this apparent trend. Insufficient failure data exist currently to perform a similar comparison for GLT-S O-rings.

Aging and periodic leak testing will continue for the remaining fixtures.

\section{$\underline{\text { References }}$}

[1] WSRC-TR-2003-00325, Rev. 4, “Task Technical and Quality Assurance Plan for Characterization and Surveillance of Model 9975 Package O-Rings and Celotex ${ }^{\circledR}$ Materials (U)”, January 2009.

[2] SRNS-TR-2008-00054, Rev. 0, “Task Technical and Quality Assurance Plan for Accelerated Aging of Viton ${ }^{\circledR}$ GLT-S O-rings for Model 9975 Shipping Packages in KAMS (U)”, January 2009.

[3] WSRC-TR-2001-0286, Rev. 4, "SRS Surveillance Program for Storage of Pu Material in KAMS”, July 2008.

[4] SRNL-TR-2009-00186, "Fourth Interim Status Report: Model 9975 PCV O-Ring Fixture Long-Term Leak Performance”, W. L. Daugherty and T. M. Stefek, June 2009

[5] WSRC-SA-2002-00008, Rev. 0, “Safety Analysis Report for Packaging - Model 9975”, December 2003.

[6] S-CLC-K-00198, Rev. 0, “KAMS 9975 Shipping Package Thermal Sensitivity Analysis”, S. Chow, October 2004.

[7] M-CLC-K-00727, “Thermal Model Study for the 9975 Package in KAMS During Facility Fire”, N. K. Gupta, June 11, 2008.

[8] L9.4-10500, Rev. 2, “Annual Maintenance and Leak Testing for the 9975 Shipping Package,” Instrumentation and Equipment Systems Section, SRNL, August 29, 2007.

[9] ANSI Standard N14.5-97, “American National Standard for Radioactive Materials Leakage Tests on Packages for Shipment”, American National Standards Institute, New York, NY, February 1998.

[10] SRNL-L1400-2008-00038, “Characterization of Leak Test System for O-Ring Studies”, D. J. Trapp, December 18, 2008. 
[11] SRNL-TR-2010-00136, Rev. 1, "Fifth Interim Status Report: Model 9975 PCV O-Ring Fixture Long-Term Leak Performance”, W. L. Daugherty and E. N. Hoffman, April 2011.

[12] Parker O-Ring Handbook, ORD-5700, Parker Seals, O-Ring Division, 2001.

[13] WSRC-TR-2007-00276, Rev. 0, “Task Technical and Quality Assurance Plan for Model 9975 O-ring Life Prediction (U)”, January 2008.

[14] SRNS-TR-2009-00259, “Lifetime Prediction for Model 9975 O-Rings in KAMS”, E. N. Hoffman and T. E. Skidmore, November 2009.

[15] SRNS-TR-2008-00290, Rev. 0, "Summary and Matrix 9975 Shipping Package Qualification Program for Extended Storage of Plutonium in the K Area Complex”, J. A. Radder, Savannah River Nuclear Solutions, Aiken, SC, November 2008.

[16] M-CLC-K-00729, Rev. 0, “Thermal Analysis of the 9975 Package with Softwood-Based Fiberboard during KAMS Facility Fire”, N. K. Gupta, June 11, 2008, and

M-CLC-K-00727, Rev. 0, “Thermal Model Study for the 9975 Package in KAMS during Facility Fire”, N. K. Gupta and D. Tamburello, June 11, 2008. 
Table 1. Test Matrix Variables for O-Ring Experiment

\begin{tabular}{|c|c|c|}
\hline $\begin{array}{l}\text { Test } \\
\text { Variable }\end{array}$ & Values Tested & Basis for Values Tested \\
\hline \multirow[t]{3}{*}{ Temperature } & $\begin{array}{l}200^{\circ} \mathrm{F} \\
\left(93^{\circ} \mathrm{C}\right)\end{array}$ & $\begin{array}{l}\text { With loss of ventilation in the KAC facility, the } \\
\text { maximum ambient temperature is } 137^{\circ} \mathrm{F} \text { [15], and the } \\
\text { corresponding PCV O-ring temperature is } 199^{\circ} \mathrm{F} \text { [16]. }\end{array}$ \\
\hline & $\begin{array}{l}300^{\circ} \mathrm{F} \\
\left(149^{\circ} \mathrm{C}\right)\end{array}$ & $\begin{array}{l}\text { The maximum allowable temperature for the PCV O- } \\
\text { rings for continuous operation is } 300^{\circ} \mathrm{F} \text { [5]. }\end{array}$ \\
\hline & $\begin{array}{l}350,400,450^{\circ} \mathrm{F} \\
\left(177,204,232^{\circ} \mathrm{C}\right)\end{array}$ & $\begin{array}{l}\text { Elevated temperatures added to increase the likelihood } \\
\text { of seeing O-ring failures in shorter test periods. }\end{array}$ \\
\hline \multirow[t]{3}{*}{$\begin{array}{l}\text { Radiation } \\
\text { Dose }\end{array}$} & $\begin{array}{ll}\text { 2E5 } & \text { Rad in } 72 \\
\text { min } & \end{array}$ & $\begin{array}{l}\text { The bounding dose rate for the PCV is } 2 \mathrm{rad} / \mathrm{hr} \text {. A total } \\
\text { dose of } 2 \mathrm{E} 5 \mathrm{rad} \text { represents ten years of storage. }\end{array}$ \\
\hline & $\begin{array}{l}\text { 2E5 } \\
>200 \mathrm{hr}\end{array}$ & $\begin{array}{l}\text { Longer-term exposure may reveal the added effect of } \\
\text { diffusion-limited oxidation (DLO) that only occurs with } \\
\text { long-term exposure. }\end{array}$ \\
\hline & None & $\begin{array}{l}\text { Many packages will have little radiation exposure. This } \\
\text { also serves as an experimental control. }\end{array}$ \\
\hline \multirow[t]{3}{*}{$\begin{array}{l}\text { O-Ring } \\
\text { Lubrication }\end{array}$} & $\begin{array}{l}\text { Silicone high- } \\
\text { vacuum grease }\end{array}$ & It is specified in assembly of the 9975 package [3]. \\
\hline & Krytox® 240AC & $\begin{array}{l}\text { It has been used on } 9975 \text { O-rings at DOE facilities. It is } \\
\text { used on lid components of the } 9975 \text { PCV and SCV [3]. }\end{array}$ \\
\hline & None & $\begin{array}{l}\text { It supplies comparative control data. Also, it is possible } \\
\text { that the O-rings may be mistakenly installed without } \\
\text { grease. }\end{array}$ \\
\hline
\end{tabular}


Table 2. Summary of test parameters for fixtures

\begin{tabular}{|c|c|c|c|c|c|}
\hline \multirow[b]{2}{*}{$\begin{array}{l}\text { Temp. } \\
{ }^{\circ} \mathbf{F}\end{array}$} & \multirow[b]{2}{*}{$\begin{array}{l}\text { Gamma } \\
\text { Dose (rad) / } \\
\text { Dose Rate }\end{array}$} & \multirow[b]{2}{*}{ Lubricant } & \multicolumn{3}{|c|}{\begin{tabular}{|l|l|} 
Fixtures Still in & Fixtures Removed from Test \\
\end{tabular}} \\
\hline & & & Test & $\begin{array}{l}\text { Failed Leak } \\
\text { Test at } \\
\text { Room Temp }\end{array}$ & $\begin{array}{l}\text { For Other } \\
\text { Reasons }\end{array}$ \\
\hline \multicolumn{6}{|c|}{ GLT O-ring Fixtures - First Test Matrix } \\
\hline 200 & 2E5 High & Normal & $\begin{array}{l}5,6,9,27,36, \\
37,40,41,42, \\
53,54,55\end{array}$ & & $15,16,23,24$ \\
\hline 200 & 2E5 Low & Normal & 10,11 & & \\
\hline 200 & No & Normal & $\begin{array}{l}1,3,43,44 \\
56,57\end{array}$ & & $13,28,29$ \\
\hline 300 & 2E5 High & Normal & $7,8,51,52 * *$ & $12,26,31$ & $\begin{array}{l}17,22,25,39, \\
45,46,47,58, \\
59,60\end{array}$ \\
\hline 300 & $\sim 2 E 5$ Low & Normal & $18,30 *$ & 32 & 21,38 \\
\hline 300 & No & Normal & $4,33^{*}, 61$ & 49 & $\begin{array}{l}2,14,48,50, \\
62\end{array}$ \\
\hline 300 & 2E5 High & None & & & 19 \\
\hline 300 & No & None & & & 34 \\
\hline 200 & No & Krytox & 35 & & \\
\hline 300 & $\sim 2 E 5$ Low & Krytox & 20 & & \\
\hline \multicolumn{6}{|c|}{ GLT O-ring Fixtures - Second Test Matrix } \\
\hline 270 & No & Normal & $14 \mathrm{~W}$ & & \\
\hline 270 & No & Normal & $21 \mathrm{~W}$ & & \\
\hline 350 & 2E5 High & Normal & & 18D & \\
\hline 350 & No & Normal & & 19D & \\
\hline 400 & 2E5 High & Normal & & 14D & \\
\hline 400 & No & Normal & & $21 \mathrm{D}$ & \\
\hline 450 & 2E5 High & Normal & & $23 \mathrm{D}$ & \\
\hline \multicolumn{6}{|c|}{ GLT-S O-ring Fixtures - Third Test Matrix } \\
\hline 200 & None & Normal & $13 \mathrm{H}, 15 \mathrm{H}$ & & \\
\hline 250 & None & Normal & $22 \mathrm{H}, 16 \mathrm{H}$ & & \\
\hline 300 & None & Normal & $29 \mathrm{H}, 34 \mathrm{H}$ & & \\
\hline 350 & None & Normal & & $38 \mathrm{H}, 39 \mathrm{H}$ & \\
\hline 400 & None & Normal & & $45 \mathrm{H}, 58 \mathrm{H}$ & \\
\hline 400 & None & Normal & & $60 \mathrm{H}, 62 \mathrm{H}$ & \\
\hline 400 & $\begin{array}{l}2 \mathrm{E} 5 \text { in } 72 \\
\text { min. }\end{array}$ & Normal & & $28 \mathrm{H}, 50 \mathrm{H}$ & \\
\hline
\end{tabular}

* Fixtures 30 and 33 have 1 failed O-ring. They remain in test pending failure of the second O-ring.

** Fixture 52 was previously reported as having 1 failed O-ring. Subsequent re-testing has shown both O-rings to be leak-tight. 
Table 3. Summary of testing GLT fixtures for permeation signal. Testing for permeation was repeated only if it was not seen on previous tests. Tests were typically terminated after 30 minutes, although a few tests continued for longer periods.

\begin{tabular}{|c|c|c|c|}
\hline $\begin{array}{l}\text { Fixture } \\
\text { Number }\end{array}$ & $\begin{array}{l}\text { \# Tests before } \\
\text { Permeation } \\
\text { Seen }\end{array}$ & $\begin{array}{l}\text { Permeation } \\
\text { Seen? }\end{array}$ & $\begin{array}{l}\text { Time to } \\
\text { Permeate }\end{array}$ \\
\hline 1 & 1 & $\mathrm{Y}$ & $10 \mathrm{~min}$ \\
\hline 3 & 1 & $\mathrm{Y}$ & $30 \mathrm{~min}$ \\
\hline 4 & 5 & $\mathrm{Y}$ & $61 \mathrm{~min}$ \\
\hline 5 & 3 & $\mathrm{Y}$ & $75 \mathrm{~min}$ \\
\hline 6 & 2 & $\mathrm{Y}$ & $5 \mathrm{~min}$ \\
\hline 7 & 1 & $\mathrm{Y}$ & $10 \mathrm{~min}$ \\
\hline 8 & 1 & $\mathrm{Y}$ & $16 \mathrm{~min}$ \\
\hline 9 & 1 & $\mathrm{Y}$ & $7 \mathrm{~min}$ \\
\hline 10 & 2 & $\mathrm{Y}$ & $11 \mathrm{~min}$ \\
\hline 11 & 1 & $\mathrm{Y}$ & $10 \mathrm{~min}$ \\
\hline 12 & 2 & $\mathrm{Y}$ & $35 \mathrm{~min}$ \\
\hline 18 & 1 & $\mathrm{Y}$ & $11 \mathrm{~min}$ \\
\hline 20 & 1 & $\mathrm{Y}$ & $30 \mathrm{~min}$ \\
\hline 26 & 1 & $\mathrm{Y}$ & $9 \mathrm{~min}$ \\
\hline 27 & 2 & $\mathrm{Y}$ & $8 \mathrm{~min}$ \\
\hline 30 & 1 & $\mathrm{Y}$ & $8 \mathrm{~min}$ \\
\hline 31 & 1 & $\mathrm{Y}$ & $10 \mathrm{~min}$ \\
\hline 32 & 1 & $\mathrm{Y}$ & $13 \mathrm{~min}$ \\
\hline 33 & 2 & $\mathrm{Y}$ & $9 \mathrm{~min}$ \\
\hline 35 & 3 & $\mathrm{Y}$ & $12 \min$ \\
\hline 36 & 3 & $\mathrm{Y}$ & $6 \mathrm{~min}$ \\
\hline 37 & 3 & $\mathrm{Y}$ & $18 \mathrm{~min}$ \\
\hline 40 & 2 & $\mathrm{Y}$ & 14 min \\
\hline 41 & 1 & $\mathrm{Y}$ & $10 \mathrm{~min}$ \\
\hline 42 & 1 & $\mathrm{Y}$ & $8 \mathrm{~min}$ \\
\hline 43 & 3 & $\mathrm{Y}$ & $30 \mathrm{~min}$ \\
\hline 44 & 1 & $\mathrm{Y}$ & $12 \mathrm{~min}$ \\
\hline 49 & 1 & $\mathrm{Y}$ & $7 \mathrm{~min}$ \\
\hline 51 & 2 & $\mathrm{Y}$ & $4 \mathrm{~min}$ \\
\hline 52 & 2 & $\mathrm{Y}$ & $7 \mathrm{~min}$ \\
\hline 53 & 1 & $\mathrm{Y}$ & $30 \mathrm{~min}$ \\
\hline 54 & 1 & $\mathrm{Y}$ & $12 \mathrm{~min}$ \\
\hline 55 & 1 & $\mathrm{Y}$ & $11 \mathrm{~min}$ \\
\hline 56 & 1 & $\mathrm{Y}$ & $10 \mathrm{~min}$ \\
\hline 57 & 1 & $\mathrm{Y}$ & $13 \mathrm{~min}$ \\
\hline 61 & 3 & $\mathrm{Y}$ & $20 \mathrm{~min}$ \\
\hline
\end{tabular}


Table 4. Summary of GLT and GLT-S O-ring leak failures

\begin{tabular}{|c|c|c|c|}
\hline & & \multicolumn{2}{|c|}{ Days at temperature before failure } \\
\hline Fixture & $\begin{array}{c}\text { Temp } \\
\left({ }^{\circ} \mathrm{F}\right)\end{array}$ & Inner & Outer \\
\hline \multicolumn{4}{|c|}{ GLT O-ring Fixtures } \\
\hline 12 & 300 & 1020 & 1020 \\
\hline 26 & 300 & 1366 & 1273 \\
\hline 30 & 300 & 1392 & N A \\
\hline 31 & 300 & 1291 & 1291 \\
\hline 32 & 300 & 1352 & 1352 \\
\hline 33 & 300 & 1466 & N A \\
\hline 49 & 300 & 1276 & 1360 \\
\hline $18 \mathrm{D}$ & 350 & 497 & 324 \\
\hline 19D & 350 & 594 & 571 \\
\hline 14D & 400 & 45 & 45 \\
\hline $21 \mathrm{D}$ & 400 & 28 & 28 \\
\hline $23 \mathrm{D}$ & 450 & 12 & 8 \\
\hline \multicolumn{4}{|c|}{ GLT-S O-ring Fixtures } \\
\hline $38 \mathrm{H}$ & 350 & 358 & 358 \\
\hline $39 \mathrm{H}$ & 350 & 114 & 114 \\
\hline $45 \mathrm{H}$ & 400 & 99 & 99 \\
\hline $58 \mathrm{H}$ & 400 & 75 & 75 \\
\hline $60 \mathrm{H}$ & 400 & 50 & 50 \\
\hline $62 \mathrm{H}$ & 400 & 50 & 50 \\
\hline $28 \mathrm{H}$ & 400 & 50 & 50 \\
\hline $50 \mathrm{H}$ & 400 & 281 & 281 \\
\hline
\end{tabular}


Table 5. Room temperature leak rate data for fixtures (for fixtures in test since last status report)

\begin{tabular}{|l|l|}
\hline \multicolumn{2}{|l|}{ Test $1,200{ }^{\circ} \mathrm{F}$} \\
\hline No rad. \\
\hline $\begin{array}{l}\text { Time at Temp } \\
\text { (months) }\end{array}$ & $\begin{array}{l}\text { Leak Rate (std } \\
\text { cc He/sec) }\end{array}$ \\
\hline Baseline & $<1.3 \mathrm{E}-9$ \\
\hline 6 & $<9.0 \mathrm{E}-10$ \\
\hline 18 & $8.0 \mathrm{E}-9$ \\
\hline 30 & $<1.2 \mathrm{E}-8$ \\
\hline 36 & $<1.2 \mathrm{E}-8$ \\
\hline 42 & $<1.2 \mathrm{E}-8$ \\
\hline 48 & $<2.0 \mathrm{E}-8$ \\
\hline 54 & $<1.0 \mathrm{E}-8$ \\
\hline 60 & $<3.0 \mathrm{E}-8$ \\
\hline & \\
\hline
\end{tabular}

\begin{tabular}{|l|l|}
\hline \multicolumn{2}{|l|}{ Test 3, $200^{\circ} \mathrm{F}$} \\
\hline \multicolumn{2}{|l|}{ No rad. } \\
\hline $\begin{array}{l}\text { Time at Temp } \\
\text { (months) }\end{array}$ & $\begin{array}{l}\text { Leak Rate (std } \\
\text { cc He/sec) }\end{array}$ \\
\hline Baseline & $<2.9$ E-9 \\
\hline 6 & 1.0 E-7 \\
\hline 15 & 2.7 E-8 \\
\hline 18 & $<1.2$ E-8 \\
\hline 31 & $<1.3$ E-8 \\
\hline 37 & $<2.0$ E-9 \\
\hline 42 & 4.0 E-9 \\
\hline 48 & 2.5 E-8 \\
\hline 54 & $<1.3$ E-8 \\
\hline 59 & $<2.8$ E-8 \\
\hline
\end{tabular}

\begin{tabular}{|l|l|}
\hline \multicolumn{2}{|l|}{ Test 5, $200^{\circ} \mathrm{F}$} \\
\hline 2E5Rad /72 min \\
\hline $\begin{array}{l}\text { Time at Temp } \\
\text { (months) }\end{array}$ & $\begin{array}{l}\text { Leak Rate (std } \\
\text { cc He/sec) }\end{array}$ \\
\hline Baseline & $<2.3 \mathrm{E}-9$ \\
\hline 6 & $1.1 \mathrm{E}-7$ \\
\hline 11 & $2.0 \mathrm{E}-8$ \\
\hline 18 & $<1.2 \mathrm{E}-8$ \\
\hline 31 & $<1.0 \mathrm{E}-8$ \\
\hline 37 & $<6.0 \mathrm{E}-9$ \\
\hline 42 & $<1.0 \mathrm{E}-8$ \\
\hline 48 & $<1.2 \mathrm{E}-8$ \\
\hline 53 & $<1.0 \mathrm{E}-8$ \\
\hline 59 & $<2.4 \mathrm{E}-8$ \\
\hline
\end{tabular}

\begin{tabular}{|l|l|}
\hline \multicolumn{2}{|l|}{ Test 6, $200^{\circ} \mathrm{F}$} \\
\hline 2E5Rad $/ 72$ min \\
\hline $\begin{array}{l}\text { Time at Temp } \\
\text { (months) }\end{array}$ & $\begin{array}{l}\text { Leak Rate (std } \\
\text { cc He/sec) }\end{array}$ \\
\hline Baseline & $3.3 \mathrm{E}-9$ \\
\hline 6 & $4.0 \mathrm{E}-8$ \\
\hline 11 & $5.5 \mathrm{E}-8$ \\
\hline 18 & $<1.2 \mathrm{E}-8$ \\
\hline 31 & $<1.8 \mathrm{E}-8$ \\
\hline 37 & $<2.2 \mathrm{E}-8$ \\
\hline 42 & $<1.2 \mathrm{E}-8$ \\
\hline 48 & $<2.8 \mathrm{E}-8$ \\
\hline 54 & $<4.0 \mathrm{E}-9$ \\
\hline 59 & $<2.0 \mathrm{E}-8$ \\
\hline
\end{tabular}

\begin{tabular}{|l|l|}
\hline \multicolumn{2}{|l|}{ Test 9, 200 ${ }^{\circ} \mathrm{F}$} \\
\hline \multicolumn{2}{|l|}{ 2E5Rad $/ 72 \mathrm{~min}$} \\
\hline $\begin{array}{l}\text { Time at Temp } \\
\text { (months) }\end{array}$ & $\begin{array}{l}\text { Leak Rate (std } \\
\text { cc He/sec) }\end{array}$ \\
\hline Baseline & $5.6 \mathrm{E}-9$ \\
\hline 6 & $9.9 \mathrm{E}-8$ \\
\hline 12 & $4.2 \mathrm{E}-8$ \\
\hline 18 & $<1.8 \mathrm{E}-8$ \\
\hline 28 & $<1.6 \mathrm{E}-8$ \\
\hline 36 & $<9.5 \mathrm{E}-10$ \\
\hline 40 & $1.0 \mathrm{E}-7$ \\
\hline 42 & $<1.0 \mathrm{E}-8$ \\
\hline 48 & $<3.0 \mathrm{E}-8$ \\
\hline 53 & $2.6 \mathrm{E}-8$ \\
\hline
\end{tabular}

\begin{tabular}{|l|l|}
\hline \multicolumn{2}{|l|}{ Test 10, $200^{\circ} \mathrm{F}$} \\
\hline \multicolumn{2}{|l|}{ 2E5Rad $/ 240 \mathrm{hr}$} \\
\hline $\begin{array}{l}\text { Time at Temp } \\
\text { (months) }\end{array}$ & $\begin{array}{l}\text { Leak Rate (std } \\
\text { cc He/sec) }\end{array}$ \\
\hline Baseline & $7.4 \mathrm{E}-8$ \\
\hline 6 & $1.2 \mathrm{E}-7$ \\
\hline 13 & $<1.2 \mathrm{E}-8$ \\
\hline 26 & $5.6 \mathrm{E}-9$ \\
\hline 33 & $<8.0 \mathrm{E}-9$ \\
\hline 36 & $2.6 \mathrm{E}-9$ \\
\hline 42 & $5.4 \mathrm{E}-8$ \\
\hline 48 & $<1.3 \mathrm{E}-9$ \\
\hline 54 & $<2.2 \mathrm{E}-8$ \\
\hline & \\
\hline
\end{tabular}

\begin{tabular}{|l|l|}
\hline \multicolumn{2}{|l|}{ Test 11, $200^{\circ} \mathrm{F}$} \\
\hline $1.4 \mathrm{E} 5$ Rad $/ 479 \mathrm{hr}$ \\
\hline $\begin{array}{l}\text { Time at Temp } \\
\text { (months) }\end{array}$ & $\begin{array}{l}\text { Leak Rate (std } \\
\text { cc He/sec) }\end{array}$ \\
\hline Baseline & $<1.5 \mathrm{E}-9$ \\
\hline 8 & $<1.3 \mathrm{E}-8$ \\
\hline 14 & $<8.8 \mathrm{E}-9$ \\
\hline 25 & $<1.0 \mathrm{E}-8$ \\
\hline 31 & $<4.0 \mathrm{E}-9$ \\
\hline 35 & $4.0 \mathrm{E}-9$ \\
\hline 42 & $<1.8 \mathrm{E}-8$ \\
\hline 48 & $7.3 \mathrm{E}-9$ \\
\hline 54 & $<2.6 \mathrm{E}-8$ \\
\hline
\end{tabular}

\begin{tabular}{|l|l|}
\hline \multicolumn{2}{|l|}{ Test 27, $200{ }^{\circ} \mathrm{F}$} \\
\hline 2E5Rad /72 min \\
\hline $\begin{array}{l}\text { Time at Temp } \\
\text { (months) }\end{array}$ & $\begin{array}{l}\text { Leak Rate } \text { (std } \\
\text { cc He/sec) }\end{array}$ \\
\hline Baseline & $1.6 \mathrm{E}-9$ \\
\hline 6 & $1.5 \mathrm{E}-8$ \\
\hline 12 & $<1.0 \mathrm{E}-8$ \\
\hline 19 & $<3.2 \mathrm{E}-8$ \\
\hline 24 & $<1.2 \mathrm{E}-8$ \\
\hline 30 & $<1.4 \mathrm{E}-8$ \\
\hline 35 & $<4.0 \mathrm{E}-9$ \\
\hline 41 & $<1.6 \mathrm{E}+8$ \\
\hline & \\
\hline
\end{tabular}

\begin{tabular}{|l|l|}
\hline \multicolumn{2}{|l|}{ Test 35, $200{ }^{\circ} \mathrm{F}$} \\
\hline No rad. \\
\hline $\begin{array}{l}\text { Time at Temp } \\
\text { (months) }\end{array}$ & $\begin{array}{l}\text { Leak Rate (std } \\
\text { cc He/sec) }\end{array}$ \\
\hline Baseline & (invalid) \\
\hline 6 & $1.3 \mathrm{E}-8$ \\
\hline 11 & $<1.4 \mathrm{E}-8$ \\
\hline 24 & $<1.6 \mathrm{E}-8$ \\
\hline 31 & $<3.2 \mathrm{E}-8$ \\
\hline 36 & $<1.2 \mathrm{E}-8$ \\
\hline 42 & $<1.6 \mathrm{E}-8$ \\
\hline 48 & $2.8 \mathrm{E}-8$ \\
\hline 54 & $<1.8 \mathrm{E}-8$ \\
\hline
\end{tabular}


Table 5. (continued) Room temperature leak rate data for fixtures (for fixtures in test since last status report)

\begin{tabular}{|l|l|}
\hline \multicolumn{2}{|l|}{ Test 36, $200^{\circ} \mathrm{F}$} \\
\hline 2 25Rad $/ 72$ min \\
\hline $\begin{array}{l}\text { Time at Temp } \\
\text { (months) }\end{array}$ & $\begin{array}{l}\text { Leak Rate (std } \\
\text { cc He/sec) }\end{array}$ \\
\hline Baseline & $<1.5 \mathrm{E}-9$ \\
\hline 6 & $1.3 \mathrm{E}-8$ \\
\hline 11 & $<8.0 \mathrm{E}-9$ \\
\hline 25 & $<1.8 \mathrm{E}-8$ \\
\hline 32 & $<2.8 \mathrm{E}-8$ \\
\hline 36 & $<1.0 \mathrm{E}-8$ \\
\hline 42 & $<2.0 \mathrm{E}-8$ \\
\hline 48 & $3.7 \mathrm{E}-9$ \\
\hline 53 & $<3.2 \mathrm{E}-8$ \\
\hline
\end{tabular}

\begin{tabular}{|l|l|}
\hline \multicolumn{2}{|l|}{ Test 37, $200{ }^{\circ} \mathrm{F}$} \\
\hline \multicolumn{2}{|l|}{ 2E5Rad $/ 72 \mathrm{~min}$} \\
\hline $\begin{array}{l}\text { Time at Temp } \\
\text { (months) }\end{array}$ & $\begin{array}{l}\text { Leak Rate (std } \\
\text { cc He/sec) }\end{array}$ \\
\hline Baseline & (invalid) \\
\hline 8 & $1.9 \mathrm{E}-8$ \\
\hline 11 & $<8.0 \mathrm{E}-9$ \\
\hline 24 & $<1.8 \mathrm{E}-8$ \\
\hline 32 & $<2.2 \mathrm{E}-8$ \\
\hline 36 & $<1.0 \mathrm{E}-8$ \\
\hline 41 & $<3.0 \mathrm{E}-8$ \\
\hline 47 & $<1.3 \mathrm{E}-9$ \\
\hline 53 & $<3.6 \mathrm{E}-8$ \\
\hline
\end{tabular}

\begin{tabular}{|l|l|}
\hline \multicolumn{2}{|l|}{ Test 40, $200^{\circ} \mathrm{F}$} \\
\hline \multicolumn{2}{|l|}{ 2E5Rad $/ 72 \mathrm{~min}$} \\
\hline $\begin{array}{l}\text { Time at Temp } \\
\text { (months) }\end{array}$ & $\begin{array}{l}\text { Leak Rate (std } \\
\text { cc He/sec) }\end{array}$ \\
\hline Baseline & $7.7 \mathrm{E}-9$ \\
\hline 6 & $1.5 \mathrm{E}-8$ \\
\hline 12 & $<1.0 \mathrm{E}-8$ \\
\hline 28 & $<2.6 \mathrm{E}-8$ \\
\hline 35 & $<7.0 \mathrm{E}-10$ \\
\hline 42 & $1.6 \mathrm{E}-8$ \\
\hline 48 & $4.8 \mathrm{E}-7 *$ \\
\hline 53 & $<1.2 \mathrm{E}-8$ \\
\hline & \\
\hline
\end{tabular}

* Test 40 - failed bag test at 48 months. Both O-rings ok. Later traced to leak at hose connection.

\begin{tabular}{|l|l|}
\hline \multicolumn{2}{|l|}{ Test 41, $200^{\circ} \mathrm{F}$} \\
\hline 2E5Rad /72 min \\
\hline $\begin{array}{l}\text { Time at Temp } \\
\text { (months) }\end{array}$ & $\begin{array}{l}\text { Leak Rate (std } \\
\text { cc He/sec) }\end{array}$ \\
\hline Baseline & (invalid) \\
\hline 6 & $1.3 \mathrm{E}-8$ \\
\hline 11 & $<1.0 \mathrm{E}-8$ \\
\hline 24 & $<1.9 \mathrm{E}-8$ \\
\hline 32 & $<1.8 \mathrm{E}-8$ \\
\hline 36 & $2.0 \mathrm{E}-9$ \\
\hline 42 & $<2.0 \mathrm{E}-8$ \\
\hline 48 & $2.2 \mathrm{E}-8$ \\
\hline 53 & $<3.4 \mathrm{E}-8$ \\
\hline
\end{tabular}

\begin{tabular}{|l|l|}
\hline \multicolumn{2}{|l|}{ Test 42, $200{ }^{\circ} \mathrm{F}$} \\
\hline 2E5Rad /72 min \\
\hline $\begin{array}{l}\text { Time at Temp } \\
\text { (months) }\end{array}$ & $\begin{array}{l}\text { Leak Rate (std } \\
\text { cc He/sec) }\end{array}$ \\
\hline Baseline & (invalid) \\
\hline 6 & $1.5 \mathrm{E}-8$ \\
\hline 11 & $<1.0 \mathrm{E}-8$ \\
\hline 24 & $<1.8 \mathrm{E}-8$ \\
\hline 32 & $<1.8 \mathrm{E}-8$ \\
\hline 36 & $1.8 \mathrm{E}-9$ \\
\hline 42 & $<2.2 \mathrm{E}-8$ \\
\hline 48 & $<1.2 \mathrm{E}-8$ \\
\hline 53 & $<2.8 \mathrm{E}-8$ \\
\hline
\end{tabular}

\begin{tabular}{|l|l|}
\hline \multicolumn{2}{|l|}{ Test 43, $200^{\circ} \mathrm{F}$} \\
\hline \multicolumn{2}{|l|}{ No rad. } \\
\hline $\begin{array}{l}\text { Time at Temp } \\
\text { (months) }\end{array}$ & $\begin{array}{l}\text { Leak Rate (std } \\
\text { cc He/sec) }\end{array}$ \\
\hline Baseline & (invalid) \\
\hline 6 & 2.0 E-8 \\
\hline 12 & $<1.0$ E-8 \\
\hline 24 & $<1.8$ E-8 \\
\hline 33 & $<3.0$ E-8 \\
\hline 35 & 1.8 E-9 \\
\hline 42 & $<5.8$ E-8 \\
\hline 48 & $<1.3$ E-9 \\
\hline 53 & $<3.6$ E-8 \\
\hline
\end{tabular}

\begin{tabular}{|l|l|}
\hline \multicolumn{2}{|l|}{ Test 44, $200{ }^{\circ} \mathrm{F}$} \\
\hline No rad. \\
\hline $\begin{array}{l}\text { Time at Temp } \\
\text { (months) }\end{array}$ & $\begin{array}{l}\text { Leak Rate (std } \\
\text { cc He/sec) }\end{array}$ \\
\hline Baseline & (invalid) \\
\hline 6 & 1.5 E-8 \\
\hline 12 & $<1.6$ E-8 \\
\hline 24 & $<1.8 \mathrm{E}-8$ \\
\hline 32 & $<2.0 \mathrm{E}-8$ \\
\hline 36 & $1.8 \mathrm{E}-9$ \\
\hline 42 & $1.1 \mathrm{E}-7$ \\
\hline 48 & $<1.6 \mathrm{E}-8$ \\
\hline 54 & $<2.4 \mathrm{E}-8$ \\
\hline
\end{tabular}

\begin{tabular}{|l|l|}
\hline \multicolumn{2}{|l|}{ Test 53, 200 ${ }^{\circ} \mathrm{F}$} \\
\hline 2E5Rad /72 min \\
\hline $\begin{array}{l}\text { Time at Temp } \\
\text { (months) }\end{array}$ & $\begin{array}{l}\text { Leak Rate (std } \\
\text { cc He/sec) }\end{array}$ \\
\hline Baseline & (invalid) \\
\hline 6 & 1.8 E-8 \\
\hline 11 & $<1.0$ E-8 \\
\hline 25 & $<1.8 \mathrm{E}-8$ \\
\hline 32 & $<1.8 \mathrm{E}-8$ \\
\hline 36 & $1.8 \mathrm{E}-9$ \\
\hline 42 & $<1.2 \mathrm{E}-8$ \\
\hline 48 & $<2.2 \mathrm{E}-8$ \\
\hline 54 & $<3.2 \mathrm{E}-8$ \\
\hline
\end{tabular}

\begin{tabular}{|l|l|}
\hline \multicolumn{2}{|l|}{ Test $54, \quad 200{ }^{\circ} \mathrm{F}$} \\
\hline 2 2E5Rad $/ 72$ min \\
\hline $\begin{array}{l}\text { Time at Temp } \\
\text { (months) }\end{array}$ & $\begin{array}{l}\text { Leak Rate (std } \\
\text { cc He/sec) }\end{array}$ \\
\hline Baseline & (invalid) \\
\hline 6 & $1.8 \mathrm{E}-8$ \\
\hline 11 & $<1.2 \mathrm{E}-8$ \\
\hline 25 & $<1.8 \mathrm{E}-8$ \\
\hline 32 & $<1.2 \mathrm{E}-8$ \\
\hline 36 & $2.0 \mathrm{E}-9$ \\
\hline 42 & $<2.0 \mathrm{E}-8$ \\
\hline 48 & $<2.6 \mathrm{E}-8$ \\
\hline 54 & $<1.8 \mathrm{E}-8$ \\
\hline
\end{tabular}


Table 5. (continued) Room temperature leak rate data for fixtures (for fixtures in test since last status report)

\begin{tabular}{|l|l|}
\hline \multicolumn{2}{|l|}{ Test 55, $200^{\circ} \mathrm{F}$} \\
\hline 2 25Rad $/ 72$ min \\
\hline $\begin{array}{l}\text { Time at Temp } \\
\text { (months) }\end{array}$ & $\begin{array}{l}\text { Leak Rate (std } \\
\text { cc He/sec) }\end{array}$ \\
\hline Baseline & (invalid) \\
\hline 6 & $1.6 \mathrm{E}-8$ \\
\hline 11 & $<1.4 \mathrm{E}-8$ \\
\hline 24 & $<1.6 \mathrm{E}-8$ \\
\hline 32 & $<8.0 \mathrm{E}-9$ \\
\hline 36 & $1.1 \mathrm{E}-8$ \\
\hline 42 & $3.7 \mathrm{E}-8$ \\
\hline 48 & $3.3 \mathrm{E}-7 *$ \\
\hline 53 & $<3.0 \mathrm{E}-8$ \\
\hline
\end{tabular}

\begin{tabular}{|l|l|}
\hline \multicolumn{2}{|l|}{ Test 56, $200{ }^{\circ} \mathrm{F}$} \\
\hline No rad. \\
\hline $\begin{array}{l}\text { Time at Temp } \\
\text { (months) }\end{array}$ & $\begin{array}{l}\text { Leak Rate (std } \\
\text { cc He/sec) }\end{array}$ \\
\hline Baseline & (invalid) \\
\hline 6 & $1.3 \mathrm{E}-8$ \\
\hline 11 & $<1.8 \mathrm{E}-8$ \\
\hline 23 & $<1.8 \mathrm{E}-8$ \\
\hline 30 & $<1.0 \mathrm{E}-8$ \\
\hline 36 & $<1.2 \mathrm{E}-8$ \\
\hline 42 & $<2.4 \mathrm{E}-8$ \\
\hline 48 & $<1.0 \mathrm{E}-8$ \\
\hline 53 & $<2.2 \mathrm{E}-8$ \\
\hline
\end{tabular}

\begin{tabular}{|l|l|}
\hline \multicolumn{2}{|l|}{ Test 57, $200^{\circ} \mathrm{F}$} \\
\hline \multicolumn{2}{|l|}{ No rad. } \\
\hline $\begin{array}{l}\text { Time at Temp } \\
\text { (months) }\end{array}$ & $\begin{array}{l}\text { Leak Rate (std } \\
\text { cc He/sec) }\end{array}$ \\
\hline Baseline & (invalid) \\
\hline 6 & $1.6 \mathrm{E}-8$ \\
\hline 11 & $<1.2 \mathrm{E}-8$ \\
\hline 23 & $<2.4 \mathrm{E}-8$ \\
\hline 31 & $<1.2 \mathrm{E}-8$ \\
\hline 33 & $<1.0 \mathrm{E}-8$ \\
\hline 42 & $<4.4 \mathrm{E}-8$ \\
\hline 47 & $<1.3 \mathrm{E}-9$ \\
\hline 53 & $<2.6 \mathrm{E}-8$ \\
\hline
\end{tabular}

* Test 55 - failed bag test at 48 months. Both O-rings ok. Later traced to leak at hose connection.

\begin{tabular}{|l|l|}
\hline \multicolumn{2}{|l|}{ Test 4, $300{ }^{\circ} \mathrm{F}$} \\
\hline No rad. \\
\hline $\begin{array}{l}\text { Time at Temp } \\
\text { (months) }\end{array}$ & $\begin{array}{l}\text { Leak Rate (std } \\
\text { cc He/sec) }\end{array}$ \\
\hline Baseline & $<1.8 \mathrm{E}-9$ \\
\hline 6 & $1.6 \mathrm{E}-8$ \\
\hline 12 & $2.5 \mathrm{E}-8$ \\
\hline 19 & $<8.0 \mathrm{E}-9$ \\
\hline 32 & $<1.0 \mathrm{E}-8$ \\
\hline 38 & $<8.0 \mathrm{E}-9$ \\
\hline 42 & $<1.4 \mathrm{E}-8$ \\
\hline 48 & $<3.0 \mathrm{E}-8$ \\
\hline 52 & $<1.2 \mathrm{E}-8$ \\
\hline 55 & $<3.6 \mathrm{E}-8$ \\
\hline 57 & $6.4 \mathrm{E}-8$ \\
\hline 59 & $<2.8 \mathrm{E}-8$ \\
\hline 62 & $<2.8 \mathrm{E}-8$ \\
\hline
\end{tabular}

\begin{tabular}{|l|l|}
\hline \multicolumn{2}{|l|}{ Test 7, $300^{\circ} \mathrm{F}$} \\
\hline \multicolumn{2}{|l|}{ 2E5Rad /72 min } \\
\hline $\begin{array}{l}\text { Time at Temp } \\
\text { (months) }\end{array}$ & $\begin{array}{l}\text { Leak Rate (std } \\
\text { cc He/sec) }\end{array}$ \\
\hline Baseline & 4.2 E-8 \\
\hline 6 & 8.6 E-8 \\
\hline 14 & $<1.1$ E-8 \\
\hline 17 & $<1.0$ E-8 \\
\hline 33 & $<1.2$ E-8 \\
\hline 37 & 2.4 E-9 \\
\hline 42 & $<9.7$ E-10 \\
\hline 44 & $<2.0$ E-8 \\
\hline 48 & $<1.3$ E-8 \\
\hline 51 & 1.9 E-7 \\
\hline 53 & 2.4 E-7 $*$ \\
\hline 57 & $<2.2$ E-8 \\
\hline 59 & 8.2 E-8 \\
\hline
\end{tabular}

\begin{tabular}{|l|l|}
\hline \multicolumn{2}{|l|}{ Test $8,300^{\circ} \mathrm{F}$} \\
\hline \multicolumn{2}{|l|}{ 2ERad $/ 72 \mathrm{~min}$} \\
\hline $\begin{array}{l}\text { Time at Temp } \\
\text { (months) }\end{array}$ & $\begin{array}{l}\text { Leak Rate (std } \\
\text { cc He/sec) }\end{array}$ \\
\hline Baseline & $2.0 \mathrm{E}-8$ \\
\hline 6 & $1.1 \mathrm{E}-7$ \\
\hline 12 & $<1.1 \mathrm{E}-8$ \\
\hline 18 & $<1.0 \mathrm{E}-8$ \\
\hline 37 & $<1.2 \mathrm{E}-8$ \\
\hline 42 & $4.4 \mathrm{E}-9$ \\
\hline 47 & $<1.6 \mathrm{E}-8$ \\
\hline 52 & $1.1 \mathrm{E}-7$ \\
\hline 55 & $<4.2 \mathrm{E}-8$ \\
\hline 56 & $>9 \mathrm{E}-5 * *$ \\
\hline 59 & $<2.8 \mathrm{E}-8$ \\
\hline 62 & $<1.6 \mathrm{E}-8$ \\
\hline & \\
\hline
\end{tabular}

* Test 7 - failed bag test at 53 months. Both O-rings ok. Later traced to leak at hose connection.

** Test 8 - failed bag test at 56 months. Both O-rings ok. Later traced to leak at hose connection. 
Table 5. (continued) Room temperature leak rate data for fixtures (for fixtures in test since last status report)

\begin{tabular}{|l|l|}
\hline \multicolumn{2}{|l|}{ Test 12, $300^{\circ} \mathrm{F}$} \\
\hline 2E5Rad $/ 72 \mathrm{~min}$ \\
\hline $\begin{array}{l}\text { Time at Temp } \\
\text { (months) }\end{array}$ & $\begin{array}{l}\text { Leak Rate (std } \\
\text { cc He/sec) }\end{array}$ \\
\hline Baseline & $<1.3 \mathrm{E}-8$ \\
\hline 5 & $2.0 \mathrm{E}-8$ \\
\hline 9 & $<1.4 \mathrm{E}-8$ \\
\hline 20 & $<1.4 \mathrm{E}-8$ \\
\hline 24 & $1.1 \mathrm{E}-8$ \\
\hline 30 & $8.7 \mathrm{E}-9$ \\
\hline 34 & $>5 \mathrm{E}-6 *$ \\
\hline & \\
\hline & \\
\hline & \\
\hline & \\
\hline
\end{tabular}

\begin{tabular}{|l|l|}
\hline \multicolumn{2}{|l|}{ Test 18, $300{ }^{\circ} \mathrm{F}$} \\
\hline 2E5Rad /246 hr \\
\hline $\begin{array}{l}\text { Time at Temp } \\
\text { (months) }\end{array}$ & $\begin{array}{l}\text { Leak Rate (std } \\
\text { cc He/sec) }\end{array}$ \\
\hline Baseline & $<1.5 \mathrm{E}-9$ \\
\hline 7 & $<1.1 \mathrm{E}-8$ \\
\hline 10 & $<6.0 \mathrm{E}-9$ \\
\hline 26 & $<1.8 \mathrm{E}-8$ \\
\hline 29 & $2.6 \mathrm{E}-9$ \\
\hline 36 & $6.2 \mathrm{E}-8$ \\
\hline 39 & $* *$ \\
\hline 42 & $9.4 \mathrm{E}-8$ \\
\hline 46 & $1.3 \mathrm{E}-8$ \\
\hline 47 & $<2.6 \mathrm{E}-8$ \\
\hline 50 & $<3.6 \mathrm{E}-8$ \\
\hline
\end{tabular}

\begin{tabular}{|l|l|}
\hline \multicolumn{2}{|l|}{ Test 20, $300{ }^{\circ} \mathrm{F}$} \\
\hline \multicolumn{2}{|l|}{$1.75 \mathrm{E} 5 \mathrm{Rad} / 562 \mathrm{hr}$} \\
\hline $\begin{array}{l}\text { Time at Temp } \\
\text { (months) }\end{array}$ & $\begin{array}{l}\text { Leak Rate (std } \\
\text { cc He/sec) }\end{array}$ \\
\hline Baseline & $<1.2 \mathrm{E}-8$ \\
\hline 6 & $3.0 \mathrm{E}-8$ \\
\hline 13 & $<4.8 \mathrm{E}-8$ \\
\hline 27 & $<1.8 \mathrm{E}-8$ \\
\hline 33 & $<6.0 \mathrm{E}-9$ \\
\hline 42 & $<7.2 \mathrm{E}-10$ \\
\hline 45 & $<2.0 \mathrm{E}-8$ \\
\hline 48 & $<2.0 \mathrm{E}-8$ \\
\hline 51 & $8.2 \mathrm{E}-8$ \\
\hline 55 & $3.7 \mathrm{E}-8$ \\
\hline 58 & $<1.6 \mathrm{E}-8$ \\
\hline
\end{tabular}

* Test 12 - Both O-rings failed at 34 months.

** Test 18 - Overall fixture test at 39 months not successful, but each O-ring passed individually

\begin{tabular}{|l|l|}
\hline \multicolumn{2}{|l|}{ Test 26, $300^{\circ} \mathrm{F}$} \\
\hline \multicolumn{2}{|l|}{ 2E5Rad $/ 72 \mathrm{~min}$} \\
\hline $\begin{array}{l}\text { Time at Temp } \\
\text { (months) }\end{array}$ & $\begin{array}{l}\text { Leak Rate (std } \\
\text { cc He/sec) }\end{array}$ \\
\hline Baseline & (invalid) \\
\hline 6 & $1.8 \mathrm{E}-8$ \\
\hline 12 & $<1.0 \mathrm{E}-8$ \\
\hline 29 & $<2.0 \mathrm{E}-8$ \\
\hline 36 & $<1.0 \mathrm{E}-8$ \\
\hline 41 & $<2.0 \mathrm{E}-8$ \\
\hline 42 & $>9.0 \mathrm{E}-5 *$ \\
\hline 45 & $1.7 \mathrm{E}-6 *$ \\
\hline & \\
\hline & \\
\hline & \\
\hline & \\
\hline
\end{tabular}

\begin{tabular}{|l|l|}
\hline \multicolumn{2}{|l|}{ Test 30, $300{ }^{\circ} \mathrm{F}$} \\
\hline 2E5Rad $/ 300 \mathrm{hr}$ \\
\hline $\begin{array}{l}\text { Time at Temp } \\
\text { (months) }\end{array}$ & $\begin{array}{l}\text { Leak Rate (std } \\
\text { cc He/sec) }\end{array}$ \\
\hline Baseline & $5.6 \mathrm{E}-8$ \\
\hline 6 & $1.5 \mathrm{E}-8$ \\
\hline 11 & $<1.8 \mathrm{E}-8$ \\
\hline 24 & $<2.0 \mathrm{E}-8$ \\
\hline 32 & $<3.0 \mathrm{E}-8$ \\
\hline 36 & $5.3 \mathrm{E}-9$ \\
\hline 42 & $2.1 \mathrm{E}-9$ \\
\hline 46 & $5.6 \mathrm{E}-7 * *$ \\
\hline 48 & $3.6 \mathrm{E}-8$ \\
\hline 51 & $2.4 \mathrm{E}-8$ \\
\hline & \\
\hline & \\
\hline
\end{tabular}

\begin{tabular}{|l|l|}
\hline \multicolumn{2}{|l|}{ Test 33, $300^{\circ} \mathrm{F}$} \\
\hline No rad. \\
\hline $\begin{array}{l}\text { Time at Temp } \\
\text { (months) }\end{array}$ & $\begin{array}{l}\text { Leak Rate (std } \\
\text { cc He/sec) }\end{array}$ \\
\hline Baseline & (invalid) \\
\hline 6 & $1.3 \mathrm{E}-8$ \\
\hline 10 & $<2.0 \mathrm{E}-8$ \\
\hline 22 & $<1.8 \mathrm{E}-8$ \\
\hline 29 & $<2.6 \mathrm{E}-8$ \\
\hline 36 & $<1.0 \mathrm{E}-9$ \\
\hline 38 & $<3.2 \mathrm{E}-8$ \\
\hline 42 & $* * *$ \\
\hline 45 & $4.7 \mathrm{E}-8$ \\
\hline 48 & $1.7 \mathrm{E}-6 * * *$ \\
\hline 50 & $2.8 \mathrm{E}-8$ \\
\hline 53 & $2.4 \mathrm{E}-8$ \\
\hline
\end{tabular}

* Test 26 - outer O-ring failed at 42 months. Inner O-ring failed at 45 months.

** Test 30 - Inner O-ring failed at 46 months. Subsequent tests on outer O-ring only (not corrected for He concentration).

*** Test 33 - Overall fixture test at 42 months not successful, but each O-ring passed individually. Inner O-ring failed at 48 months. Subsequent tests on outer O-ring only (not corrected for He concentration). 
Table 5. (continued) Room temperature leak rate data for fixtures (for fixtures in test since last status report)

\begin{tabular}{|l|l|}
\hline Test 49, $300^{\circ} \mathrm{F}$ \\
\hline No rad. \\
\hline $\begin{array}{l}\text { Time at Temp } \\
\text { (months) }\end{array}$ & $\begin{array}{l}\text { Leak Rate (std } \\
\text { cc He/sec) }\end{array}$ \\
\hline Baseline & (invalid) \\
\hline 6 & $1.6 \mathrm{E}-8$ \\
\hline 11 & $<6.0 \mathrm{E}-9$ \\
\hline 30 & $<1.8 \mathrm{E}-8$ \\
\hline 36 & $<1.4 \mathrm{E}-8$ \\
\hline 42 & $1.7 \mathrm{E}-7 *$ \\
\hline 44 & 6 E-8 \\
\hline 45 & $3.4 \mathrm{E}-7 *$ \\
\hline & \\
\hline & \\
\hline & \\
\hline & \\
\hline
\end{tabular}

\begin{tabular}{|l|l|}
\hline \multicolumn{2}{|l|}{ Test 51, $300{ }^{\circ} \mathrm{F}$} \\
\hline 2E5Rad $/ 72 \mathrm{~min}$ \\
\hline $\begin{array}{l}\text { Time at Temp } \\
\text { (months) }\end{array}$ & $\begin{array}{l}\text { Leak Rate (std } \\
\text { cc He/sec) }\end{array}$ \\
\hline Baseline & $4.3 \mathrm{E}-8$ \\
\hline 6 & $5.2 \mathrm{E}-8$ \\
\hline 11 & $<8.0 \mathrm{E}-9$ \\
\hline 21 & $<2.0 \mathrm{E}-9$ \\
\hline 28 & $<3.2 \mathrm{E}-8$ \\
\hline 36 & $<6.7 \mathrm{E}-10$ \\
\hline 39 & $<1.6 \mathrm{E}-8$ \\
\hline 43 & $6.5 \mathrm{E}-8$ \\
\hline 45 & $3.9 \mathrm{E}-6 * *$ \\
\hline 48 & $<1.8 \mathrm{E}-8$ \\
\hline 51 & $<2.4 \mathrm{E}-8$ \\
\hline & \\
\hline
\end{tabular}

\begin{tabular}{|l|l|}
\hline \multicolumn{2}{|l|}{ Test 52, $300^{\circ} \mathrm{F}$} \\
\hline \multicolumn{2}{|l|}{ 2E5Rad $/ 72$ min } \\
\hline $\begin{array}{l}\text { Time at Temp } \\
\text { (months) }\end{array}$ & $\begin{array}{l}\text { Leak Rate (std } \\
\text { cc He/sec) }\end{array}$ \\
\hline Baseline & (invalid) \\
\hline 6 & $1.8 \mathrm{E}-8$ \\
\hline 11 & $<1.0 \mathrm{E}-8$ \\
\hline 21 & $<2.4 \mathrm{E}-8$ \\
\hline 27 & $<2.8 \mathrm{E}-8$ \\
\hline 32 & $<1.0 \mathrm{E}-8$ \\
\hline 36 & $<2.6 \mathrm{E}-8$ \\
\hline 36 & $4.3 \mathrm{E}-7 * * *$ \\
\hline 39 & $<4.0 \mathrm{E}-9 * * *$ \\
\hline 42 & $<7.2 \mathrm{E}-8 * * *$ \\
\hline 45 & $<2.6 \mathrm{E}-8$ \\
\hline 48 & $<3.8 \mathrm{E}-8$ \\
\hline
\end{tabular}

* Test 49 - inner O-ring failed at 42 months. Subsequent results on outer O-ring only. Outer O-Ring failed at 45 months.

** Test 51 - failed bag test at 45 months. Both O-rings ok. Later traced to leak at hose connection. *** Test 52 - outer O-ring apparently failed at 36 months. Test of inner O-ring only at 39 months. Test both O-rings at 42 months - both ok. Subsequent tests on both O-rings.

\begin{tabular}{|l|l|}
\hline \multicolumn{2}{|l|}{ Test 61, $300^{\circ} \mathrm{F}$} \\
\hline No rad. \\
\hline $\begin{array}{l}\text { Time at Temp } \\
\text { (months) }\end{array}$ & $\begin{array}{l}\text { Leak Rate (std } \\
\text { cc He/sec) }\end{array}$ \\
\hline Baseline & (invalid) \\
\hline 6 & $1.8 \mathrm{E}-8$ \\
\hline 11 & $<1.0 \mathrm{E}-8$ \\
\hline 23 & $<1.6 \mathrm{E}-8$ \\
\hline 30 & $<2.0 \mathrm{E}-8$ \\
\hline 36 & $1.8 \mathrm{E}-8$ \\
\hline 42 & $4.7 \mathrm{E}-8$ \\
\hline 47 & $2.4 \mathrm{E}-7 *$ \\
\hline 51 & $<2.2 \mathrm{E}-8$ \\
\hline 53 & $<1.2 \mathrm{E}-8$ \\
\hline
\end{tabular}

* Test 61 - failed bag test at 47 months. Both O-rings ok. Later traced to leak at hose connection. 
Table 5. (continued) Room temperature leak rate data for fixtures (for fixtures in test since last status report)

\begin{tabular}{|c|c|}
\hline \multicolumn{2}{|c|}{ Test $18 \mathrm{D}, 350^{\circ} \mathrm{F}$} \\
\hline 2E5Rad /72 m & \\
\hline $\begin{array}{l}\text { Time at Temp } \\
\text { (months) }\end{array}$ & $\begin{array}{l}\text { Leak Rate (std } \\
\text { cc He/sec) }\end{array}$ \\
\hline Baseline & $<8.0$ E-9 \\
\hline 0.3 & $1.6 \mathrm{E}-8$ \\
\hline 0.9 & $3.2 \mathrm{E}-8$ \\
\hline 1.5 & $<8.1$ E-9 \\
\hline 2.2 & $<1.9$ E-9 \\
\hline 3.0 & $5.0 \mathrm{E}-8$ \\
\hline 3.5 & $6.1 \mathrm{E}-9$ \\
\hline 4.2 & $9.9 \mathrm{E}-10$ \\
\hline 4.7 & $3.6 \mathrm{E}-9$ \\
\hline 5.4 & $1.9 \mathrm{E}-8$ \\
\hline 5.9 & $1.3 \mathrm{E}-9$ \\
\hline 6.4 & $2.0 \mathrm{E}-8$ \\
\hline 7.1 & 3.3 E-9 \\
\hline 7.6 & $<6.0$ E-9 \\
\hline 8.0 & $<6.0$ E-9 \\
\hline 8.5 & $<9.8 \mathrm{E}-10$ \\
\hline 8.9 & $<1.8 \mathrm{E}-8$ \\
\hline 9.5 & $<8.8$ E-10 \\
\hline 10.0 & $<7.4$ E-10 \\
\hline 10.6 & $6.0 \mathrm{E}-5 *$ \\
\hline 11.0 & $3.8 \mathrm{E}-8$ \\
\hline 11.6 & $<4.6 \mathrm{E}-8$ \\
\hline 12.3 & $<2.8 \mathrm{E}-8$ \\
\hline 12.6 & $<5.8 \mathrm{E}-8$ \\
\hline 13.2 & 8.9 E-9 \\
\hline 13.9 & $9.4 \mathrm{E}-8$ \\
\hline 14.5 & $1.8 \mathrm{E}-8$ \\
\hline 15.2 & $5.4 \mathrm{E}-8$ \\
\hline 15.8 & 5.9 E-8 \\
\hline 16.3 & 1 E-6* \\
\hline
\end{tabular}

\begin{tabular}{|c|c|}
\hline Test 19D, 350 & \\
\hline No rad. & \\
\hline $\begin{array}{l}\text { Time at Temp } \\
\text { (months) }\end{array}$ & $\begin{array}{l}\text { Leak Rate (std } \\
\text { cc He/sec) }\end{array}$ \\
\hline Baseline & $2.8 \mathrm{E}-8$ \\
\hline 0.3 & $<7.9$ E-9 \\
\hline 0.9 & 2.3 E-8 \\
\hline 1.5 & $<8.6$ E-9 \\
\hline 2.2 & $<1.9$ E-9 \\
\hline 3.0 & $2.2 \mathrm{E}-8$ \\
\hline 3.5 & $<2.8$ E-9 \\
\hline 4.2 & $1.4 \mathrm{E}-9$ \\
\hline 4.7 & $2.0 \mathrm{E}-8$ \\
\hline 5.3 & 7.6 E-9 \\
\hline 5.9 & 1.5 E-9 \\
\hline 6.4 & $4.8 \mathrm{E}-9$ \\
\hline 7.1 & $<8.0$ E-9 \\
\hline 7.6 & $<1.0 \mathrm{E}-8$ \\
\hline 8.0 & $<1.0 \mathrm{E}-8$ \\
\hline 8.5 & $<1.0$ E-9 \\
\hline 9.0 & $<2.2$ E-8 \\
\hline 9.6 & $<8.8 \mathrm{E}-10$ \\
\hline 10.1 & $<7.0 \mathrm{E}-10$ \\
\hline 10.8 & 3.4 E-8 \\
\hline 11.5 & $<1.2 \mathrm{E}-8$ \\
\hline 14.8 & 5.9 E-9 \\
\hline 15.4 & $1.3 \mathrm{E}-8$ \\
\hline 16.0 & $1.5 \mathrm{E}-8$ \\
\hline 16.6 & $1.5 \mathrm{E}-8$ \\
\hline 17.3 & $<1.4$ E-8 \\
\hline 17.8 & $3.0 \mathrm{E}-8$ \\
\hline 18.4 & $6.7 \mathrm{E}-8$ \\
\hline 19.0 & $1.4 \mathrm{E}-4 * *$ \\
\hline 19.5 & $>9 \mathrm{E}-5 * *$ \\
\hline
\end{tabular}

* Test 18D - outer O-ring failed at 10.6 months. Subsequent results on inner O-ring only. Inner O-ring failed at 16.3 months.

** Test 19D - outer O-ring failed at 19.0 months. Inner O-ring failed at 19.5 months.

\begin{tabular}{|l|l|}
\hline \multicolumn{2}{|l|}{ Test $14 \mathrm{~W}, 270^{\circ} \mathrm{F}$} \\
\hline No rad. \\
\hline $\begin{array}{l}\text { Time at Temp } \\
\text { (months) }\end{array}$ & $\begin{array}{l}\text { Leak Rate (std } \\
\text { cc He/sec) }\end{array}$ \\
\hline Baseline & $<1.6 \mathrm{E}-8$ \\
\hline
\end{tabular}

\begin{tabular}{|l|l|}
\hline \multicolumn{2}{|l|}{ Test $21 \mathrm{~W}, 270^{\circ} \mathrm{F}$} \\
\hline No rad. \\
\hline $\begin{array}{l}\text { Time at Temp } \\
\text { (months) }\end{array}$ & $\begin{array}{l}\text { Leak Rate (std } \\
\text { cc He/sec) }\end{array}$ \\
\hline Baseline & $<1.6 \mathrm{E}-8$ \\
\hline
\end{tabular}


Table 5. (continued) Room temperature leak rate data for fixtures (for fixtures in test since last status report)

\begin{tabular}{|l|l|}
\hline \multicolumn{2}{|l|}{ Test 13H (GLT-S), $200{ }^{\circ} \mathrm{F}$} \\
\hline \multicolumn{2}{|l|}{ No rad. } \\
\hline $\begin{array}{l}\text { Time at Temp } \\
\text { (months) }\end{array}$ & $\begin{array}{l}\text { Leak Rate (std } \\
\text { cc He/sec) }\end{array}$ \\
\hline Baseline & $<8.5 \mathrm{E}-09$ \\
\hline 0.5 & $<1.1 \mathrm{E}-08$ \\
\hline 0.9 & $2.3 \mathrm{E}-08$ \\
\hline 1.5 & $<9.5 \mathrm{E}-09$ \\
\hline 1.9 & $<1.1 \mathrm{E}-09$ \\
\hline 2.1 & $2.3 \mathrm{E}-09$ \\
\hline 2.8 & $<1.1 \mathrm{E}-09$ \\
\hline 3.4 & $1.5 \mathrm{E}-09$ \\
\hline 3.9 & $4.4 \mathrm{E}-09$ \\
\hline 4.4 & $<8.0 \mathrm{E}-09$ \\
\hline 5.2 & $2.8 \mathrm{E}-09$ \\
\hline 5.5 & $<8.0 \mathrm{E}-09$ \\
\hline 6.5 & $<1.8 \mathrm{E}-08$ \\
\hline 6.9 & $<8.9 \mathrm{E}-10$ \\
\hline 7.7 & $<7.2 \mathrm{E}-10$ \\
\hline 8.3 & $<1.8 \mathrm{E}-08$ \\
\hline 9.0 & $<1.4 \mathrm{E}-08$ \\
\hline 14 & $<1.0 \mathrm{E}-08$ \\
\hline 20 & $4.3 \mathrm{E}-7 *$ \\
\hline 25 & $<1.6 \mathrm{E}-8$ \\
\hline & \\
\hline
\end{tabular}

\begin{tabular}{|l|l|}
\hline \multicolumn{2}{|l|}{ Test 15H (GLT-S), $200{ }^{\circ} \mathrm{F}$} \\
\hline No rad. \\
\hline $\begin{array}{l}\text { Time at Temp } \\
\text { (months) }\end{array}$ & $\begin{array}{l}\text { Leak Rate } \text { (std } \\
\text { cc He/sec) }\end{array}$ \\
\hline Baseline & $<9.8 \mathrm{E}-09$ \\
\hline 0.5 & $<1.0 \mathrm{E}-08$ \\
\hline 0.9 & $3.1 \mathrm{E}-08$ \\
\hline 1.5 & $3.6 \mathrm{E}-08$ \\
\hline 1.8 & $<2.7 \mathrm{E}-09$ \\
\hline 2.2 & $3.2 \mathrm{E}-8$ \\
\hline 2.7 & $1.1 \mathrm{E}-09$ \\
\hline 3.3 & $<1.2 \mathrm{E}-09$ \\
\hline 3.9 & $1.1 \mathrm{E}-09$ \\
\hline 4.4 & $2.9 \mathrm{E}-09$ \\
\hline 5.0 & $<4.0 \mathrm{E}-09$ \\
\hline 5.7 & $3.5 \mathrm{E}-09$ \\
\hline 6.1 & $<4.0 \mathrm{E}-09$ \\
\hline 6.6 & $<9.1 \mathrm{E}-10$ \\
\hline 7.1 & $2.4 \mathrm{E}-08$ \\
\hline 7.5 & $<1.0 \mathrm{E}-09$ \\
\hline 8.2 & $<7.3 \mathrm{E}-10$ \\
\hline 8.8 & $<1.8 \mathrm{E}-08$ \\
\hline 9.5 & $<1.4 \mathrm{E}-08$ \\
\hline 14 & $1.5 \mathrm{E}-08$ \\
\hline 20 & $2.4 \mathrm{E}-7 * *$ \\
\hline 26 & $<1.0 \mathrm{E}-8$ \\
\hline
\end{tabular}

\begin{tabular}{|l|l|}
\hline \multicolumn{2}{|l|}{ Test 16H (GLT-S), $250{ }^{\circ} \mathrm{F}$} \\
\hline \multicolumn{2}{|l|}{ No rad.. } \\
\hline $\begin{array}{l}\text { Time at Temp } \\
\text { (months) }\end{array}$ & $\begin{array}{l}\text { Leak Rate (std } \\
\text { c He/sec) }\end{array}$ \\
\hline Baseline & $<9.1 \mathrm{E}-09$ \\
\hline 0.5 & $<1.1 \mathrm{E}-08$ \\
\hline 0.9 & $4.4 \mathrm{E}-07$ \\
\hline 1.2 & $<8.1 \mathrm{E}-09$ \\
\hline 1.6 & $<9.0 \mathrm{E}-10$ \\
\hline 2.0 & $1.8 \mathrm{E}-09$ \\
\hline 2.6 & $<1.2 \mathrm{E}-09$ \\
\hline 3.2 & $1.5 \mathrm{E}-09$ \\
\hline 3.7 & $6.6 \mathrm{E}-09$ \\
\hline 4.2 & $<1.2 \mathrm{E}-08$ \\
\hline 4.9 & $<8.0 \mathrm{E}-09$ \\
\hline 5.2 & $<8.0 \mathrm{E}-09$ \\
\hline 5.7 & $<8.8 \mathrm{E}-10$ \\
\hline 6.2 & $<1.6 \mathrm{E}-08$ \\
\hline 6.6 & $<8.6 \mathrm{E}-10$ \\
\hline 7.4 & $<7.2 \mathrm{E}-10$ \\
\hline 8.0 & $<1.8 \mathrm{E}-08$ \\
\hline 8.7 & $1.5 \mathrm{E}-08$ \\
\hline 9.9 & $<1.6 \mathrm{E}-08$ \\
\hline 11 & $1.5 \mathrm{E}-07$ \\
\hline 12 & $2.4 \mathrm{E}-8$ \\
\hline 14 & $3.8 \mathrm{E}-7 * * *$ \\
\hline 15 & $<1.2 \mathrm{E}-8$ \\
\hline 16 & $>9 \mathrm{E}-5 * * *$ \\
\hline 22 & $<1.8 \mathrm{E}-8$ \\
\hline & \\
\hline & \\
\hline
\end{tabular}

Test $13 \mathrm{H}$ - failed bag test at 20 months. Both O-rings ok. Later traced to leak at hose connection. Test $15 \mathrm{H}$ - failed bag test at 20 months. Both O-rings ok. Later traced to leak at hose connection. Test $16 \mathrm{H}$ - failed bag test at 18 and 16 months. Both O-rings ok. Later traced to leak at hose connection. 
Table 5. (continued) Room temperature leak rate data for fixtures (for fixtures in test since last status report)

\begin{tabular}{|c|c|}
\hline \multicolumn{2}{|c|}{ Test $22 \mathrm{H}$ (GLT-S), $250^{\circ} \mathrm{F}$} \\
\hline \multicolumn{2}{|l|}{ No rad. } \\
\hline $\begin{array}{l}\text { Time at Temp } \\
\text { (months) }\end{array}$ & $\begin{array}{l}\text { Leak Rate (std } \\
\text { cc He/sec) }\end{array}$ \\
\hline Baseline & $<9.1$ E-09 \\
\hline 0.4 & $<1.0 \mathrm{E}-08$ \\
\hline 0.9 & $3.8 \mathrm{E}-07$ \\
\hline 1.2 & 9.0 E-09 \\
\hline 1.7 & $<2.9$ E-09 \\
\hline 2.1 & 2.0 E-09 \\
\hline 2.6 & 2.6 E-09 \\
\hline 3.1 & $<1.0 \mathrm{E}-09$ \\
\hline 3.7 & $8.8 \mathrm{E}-10$ \\
\hline 4.2 & 3.7 E-09 \\
\hline 4.8 & $<8.0$ E-09 \\
\hline 5.4 & $<9.6$ E-10 \\
\hline 5.8 & $<8.0$ E-09 \\
\hline 6.4 & $<9.1 \mathrm{E}-10$ \\
\hline 6.8 & $<2.8$ E-08 \\
\hline 7.3 & $<1.1 \mathrm{E}-09$ \\
\hline 8.0 & $<7.3 \mathrm{E}-10$ \\
\hline 8.6 & $<2.0 \mathrm{E}-08$ \\
\hline 9.3 & $<2.6$ E-08 \\
\hline 11 & $<1.8 \mathrm{E}-08$ \\
\hline 12 & $<2.0 \mathrm{E}-08$ \\
\hline 13 & 3.9 E-08 \\
\hline 14 & $2.1 \mathrm{E}-5 *$ \\
\hline 16 & $3.2 \mathrm{E}-8$ \\
\hline 17 & $<3.0 \mathrm{E}-8$ \\
\hline 18 & $<6.6 \mathrm{E}-8$ \\
\hline 24 & $<1.4 \mathrm{E}-8$ \\
\hline
\end{tabular}

\begin{tabular}{|l|l|}
\hline \multicolumn{2}{|l|}{ Test 29H (GLT-S), $300{ }^{\circ} \mathrm{F}$} \\
\hline \multicolumn{2}{|l|}{ No rad. } \\
\hline $\begin{array}{l}\text { Time at Temp } \\
\text { (months) }\end{array}$ & $\begin{array}{l}\text { Leak Rate } \text { (std } \\
\text { cc He/sec) }\end{array}$ \\
\hline Baseline & $<8.2$ E-09 \\
\hline 0.5 & 1.6 E-08 \\
\hline 1.1 & $<8.1$ E-09 \\
\hline 1.7 & 6.2 E-09 \\
\hline 2.0 & $<1.0$ E-09 \\
\hline 2.5 & 1.5 E-09 \\
\hline 3.2 & $<1.1$ E-09 \\
\hline 3.8 & 2.2 E-08 \\
\hline 4.2 & 4.2 E-09 \\
\hline 4.9 & 9.9 E-09 \\
\hline 5.5 & $<9.6$ E-10 \\
\hline 5.9 & $<8.0$ E-09 \\
\hline 6.2 & $<9.1$ E-10 \\
\hline 6.4 & $<2.4$ E-08 \\
\hline 6.9 & $<1.1$ E-09 \\
\hline 7.5 & $<6.7$ E-10 \\
\hline 8.2 & $<1.8$ E-08 \\
\hline 8.8 & 1.2 E-08 \\
\hline 9.8 & $<2.0$ E-08 \\
\hline 11 & 2.9 E-08 \\
\hline 12 & $<1.0$ E-08 \\
\hline 14 & 1.1 E-7 \\
\hline 15 & $<1.4$ E-8 \\
\hline 16 & $<4.0$ E-9 \\
\hline 17 & 2.2 E-7 $* *$ \\
\hline 18 & 3.8 E-8 \\
\hline 20 & $<2.6$ E-8 \\
\hline 23 & $<2.4$ E-8 \\
\hline
\end{tabular}

\begin{tabular}{|c|c|}
\hline Test 34H (GL & $\Gamma-\mathrm{S}), 300^{\circ} \mathrm{F}$ \\
\hline No rad. & \\
\hline $\begin{array}{l}\text { Time at Temp } \\
\text { (months) }\end{array}$ & $\begin{array}{l}\text { Leak Rate (std } \\
\text { cc He/sec) }\end{array}$ \\
\hline Baseline & $<9.5$ E-09 \\
\hline 0.8 & $<1.0$ E-08 \\
\hline 1.2 & $<2.0$ E-09 \\
\hline 1.8 & $<8.0$ E-09 \\
\hline 2.4 & $<3.2$ E-09 \\
\hline 2.7 & $<1.0$ E-09 \\
\hline 3.2 & 2.2 E-09 \\
\hline 3.8 & $<1.1$ E-09 \\
\hline 4.5 & $8.8 \mathrm{E}-10$ \\
\hline 4.9 & 2.4 E-09 \\
\hline 5.6 & $<1.0 \mathrm{E}-08$ \\
\hline 6.2 & $<9.5$ E-09 \\
\hline 6.5 & $<1.2 \mathrm{E}-08$ \\
\hline 7.1 & $<9.1 \mathrm{E}-10$ \\
\hline 7.6 & $<2.4$ E-08 \\
\hline 8.1 & $<1.0$ E-09 \\
\hline 8.7 & $<6.8 \mathrm{E}-10$ \\
\hline 9.3 & $<1.6$ E-08 \\
\hline 10 & $<1.6$ E-08 \\
\hline 11 & $<1.6$ E-08 \\
\hline 12 & $<3.0$ E-08 \\
\hline 13 & $<1.2$ E-09 \\
\hline 14 & $<1.8 \mathrm{E}-8$ \\
\hline 16 & $<1.4$ E-8 \\
\hline 17 & 5.2 E-9 \\
\hline 18 & $3.2 \mathrm{E}-5 * * *$ \\
\hline 21 & $<1.7$ E-8 \\
\hline 24 & $<1.4 \mathrm{E}-8$ \\
\hline
\end{tabular}

* Test $22 \mathrm{H}$ - outer O-ring apparently failed at 16 months. Test of inner O-ring only 16 - 18 months. Test both O-rings at 24 months - both ok.

** Test $29 \mathrm{H}$ - failed bag test at 17 months. Both O-rings ok. Later traced to leak at hose connection.

*** Test $34 \mathrm{H}-$ leak at hose connection at 18 months. Subsequent tests ok. 
Table 6. Summary of compression set data* from O-ring fixtures

\begin{tabular}{|c|c|c|c|c|c|c|}
\hline Fixture ID \& History & $\begin{array}{l}\text { Time since } \\
\text { Opening }\end{array}$ & $\begin{array}{ll}\text { Comp. } & \text { Set - } \\
\text { Inner / Outer } \\
\text { O-ring }\end{array}$ & $\begin{array}{l}\text { Time since } \\
\text { Opening }\end{array}$ & $\begin{array}{lc}\text { Comp. } & \text { Set - } \\
\text { Inner / Outer } \\
\text { O-ring }\end{array}$ & $\begin{array}{l}\text { Time } \\
\text { since } \\
\text { Opening }\end{array}$ & $\begin{array}{l}\text { Comp. Set - } \\
\text { Inner / Outer } \\
\text { O-ring }\end{array}$ \\
\hline \multicolumn{7}{|c|}{ GLT O-Ring Fixtures reported previously with high temperature leak test difficulties } \\
\hline 2 (392 days at $\left.300^{\circ} \mathrm{F}\right)$ & & & & & 30 days & $62 \% / 59 \%$ \\
\hline 29 (283 days at $\left.200^{\circ} \mathrm{F}\right)$ & & & & & 30 days & $30 \% / 18 \%$ \\
\hline 38 (473 days at $\left.300^{\circ} \mathrm{F}\right)$ & $<30 \mathrm{~min}$. & $85 \%$ / 87\% & & & & \\
\hline 39 (456 days at $300^{\circ} \mathrm{F}$ ) & $<30 \mathrm{~min}$. & $77 \% / 81 \%$ & & & & \\
\hline 45 (291 days at $300^{\circ} \mathrm{F}$ ) & & & & & 30 days & $60 \% / 71 \%$ \\
\hline 46 (493 days at $300{ }^{\circ} \mathrm{F}$ ) & $<30 \mathrm{~min}$. & $76 \% / 75 \%$ & & & & \\
\hline 47 (394 days at $300^{\circ} \mathrm{F}$ ) & 1 hour & $80 \% / 81 \%$ & 5 days & $77 \% / 73 \%$ & 34 days & $68 \% / 72 \%$ \\
\hline 48 (490 days at $300^{\circ} \mathrm{F}$ ) & $<30 \mathrm{~min}$. & $84 \%$ / 84\% & & & & \\
\hline 50 (265 days at $\left.300^{\circ} \mathrm{F}\right)$ & & & & & 30 days & $42 \% / 38 \%$ \\
\hline 60 (454 days at $300^{\circ} \mathrm{F}$ ) & $<30$ min. & $88 \%$ / 89\% & & & & \\
\hline 62 (282 days at $\left.300^{\circ} \mathrm{F}\right)$ & & & & & 30 days & $50 \% / 54 \%$ \\
\hline \multicolumn{7}{|c|}{ GLT O-Ring Fixtures removed after failing room temperature leak test } \\
\hline $12\left(1020\right.$ days at $\left.300^{\circ} \mathrm{F}\right)$ & 7 minutes & $82 \% / 70 \%$ & 14 days & $75 \% / 55 \%$ & 30 days & $74 \% / 49 \%$ \\
\hline 14D (45 days at $\left.400^{\circ} \mathrm{F}\right)$ & 21 minutes & $51 \% / 77 \%$ & 9 days & $54 \% / 74 \%$ & 85 days & $45 \% / 66 \%$ \\
\hline $18 \mathrm{D}\left(497\right.$ days at $\left.350^{\circ} \mathrm{F}\right)$ & 23 minutes & $91 \% / 96 \%$ & 14 days & $93 \% / 97 \%$ & 30 days & $92 \% / 97 \%$ \\
\hline $19 \mathrm{D}\left(594\right.$ days at $\left.350^{\circ} \mathrm{F}\right)$ & 13 minutes & $95 \% / 94 \%$ & 14 days & $98 \% / 98 \%$ & 30 days & $97 \% / 97 \%$ \\
\hline $21 \mathrm{D}\left(27\right.$ days at $\left.400^{\circ} \mathrm{F}\right)$ & 27 minutes & $66 \% / 77 \%$ & 9 days & $58 \% / 69 \%$ & 80 days & $53 \% / 66 \%$ \\
\hline $23 \mathrm{D}\left(12\right.$ days at $\left.450^{\circ} \mathrm{F}\right)$ & 21 minutes & $65 \% / 70 \%$ & 14 days & $53 \% / 63 \%$ & 90 days & $54 \% / 59 \%$ \\
\hline $26\left(1410\right.$ days at $\left.300^{\circ} \mathrm{F}\right)$ & 10 minutes & $90 \% / 91 \%$ & 14 days & $88 \%$ / 89\% & 30 days & $88 \%$ / 88\% \\
\hline $31\left(1292\right.$ days at $\left.300^{\circ} \mathrm{F}\right)$ & 15 minutes & $84 \%$ / 78\% & 14 days & $80 \% / 67 \%$ & 31 days & $78 \%$ / 65\% \\
\hline $32\left(1352\right.$ days at $\left.300^{\circ} \mathrm{F}\right)$ & 14 minutes & $93 \%$ / 83\% & 14 days & $90 \% / 73 \%$ & 31 days & $89 \% / 71 \%$ \\
\hline $49\left(1360\right.$ days at $\left.300^{\circ} \mathrm{F}\right)$ & 14 minutes & $84 \%$ / 81\% & 14 days & $82 \% / 80 \%$ & 30 days & $81 \% / 79 \%$ \\
\hline \multicolumn{7}{|c|}{ GLT O-Ring Fixtures removed for other reasons } \\
\hline $28\left(630\right.$ days at $\left.200^{\circ} \mathrm{F}\right)$ & 4 hours & $68 \%$ / 62\% & 10 days & $31 \% / 28 \%$ & 230 days & $28 \%$ / 24\% \\
\hline $\begin{array}{l}62-2007 \text { ( 6 months } \\
\text { at } 300^{\circ} \mathrm{F} \text { ) }\end{array}$ & 4 hours & $66 \% / 77 \%$ & 11 days & $35 \% / 35 \%$ & 230 days & $32 \% / 31 \%$ \\
\hline \multicolumn{7}{|c|}{ GLT-S O-Ring Fixtures removed after failing room temperature leak test } \\
\hline $28 \mathrm{H}\left(50\right.$ days at $\left.400^{\circ} \mathrm{F}\right)$ & 10 minutes & $84 \% / 91 \%$ & 11 days & $80 \% / 88 \%$ & 26 days & $80 \% / 88 \%$ \\
\hline $38 \mathrm{H}\left(358\right.$ days at $\left.350^{\circ} \mathrm{F}\right)$ & 20 minutes & $92 \% / 92 \%$ & 14 days & $90 \% / 88 \%$ & 30 days & $88 \% / 87 \%$ \\
\hline $39 \mathrm{H}\left(114\right.$ days at $\left.350^{\circ} \mathrm{F}\right)$ & 15 minutes & $78 \% / 90 \%$ & 11 days & $74 \% / 89 \%$ & 26 days & $72 \% / 88 \%$ \\
\hline $45 \mathrm{H}\left(99\right.$ days at $\left.400^{\circ} \mathrm{F}\right)$ & 12 minutes & $93 \% / 93 \%$ & 11 days & $91 \% / 92 \%$ & 26 days & $91 \% / 91 \%$ \\
\hline $50 \mathrm{H}\left(281\right.$ days at $\left.400^{\circ} \mathrm{F}\right)$ & 14 minutes & $95 \% / 82 \%$ & 14 days & $93 \% / 76 \%$ & 30 days & $93 \% / 76 \%$ \\
\hline $58 \mathrm{H}\left(75\right.$ days at $\left.400^{\circ} \mathrm{F}\right)$ & 10 minutes & $83 \% / 87 \%$ & 11 days & $81 \% / 84 \%$ & 26 days & $78 \% / 84 \%$ \\
\hline $60 \mathrm{H}\left(50\right.$ days at $\left.400^{\circ} \mathrm{F}\right)$ & 7 minutes & $84 \% / 93 \%$ & 11 days & $80 \% / 90 \%$ & 26 days & $79 \% / 89 \%$ \\
\hline $62 \mathrm{H}\left(50\right.$ days at $\left.400^{\circ} \mathrm{F}\right)$ & 7 minutes & $89 \% / 91 \%$ & 11 days & $86 \% / 89 \%$ & 26 days & $85 \% / 89 \%$ \\
\hline
\end{tabular}

* Compression set is calculated per ASTM D395, Method B, as follows: comp. set $(\%)=\left(t_{i}-t_{f}\right) /\left(t_{i}-\right.$ groove depth $) * 100$

If the initial radial thickness was not recorded, 0.139 inch is assumed. 


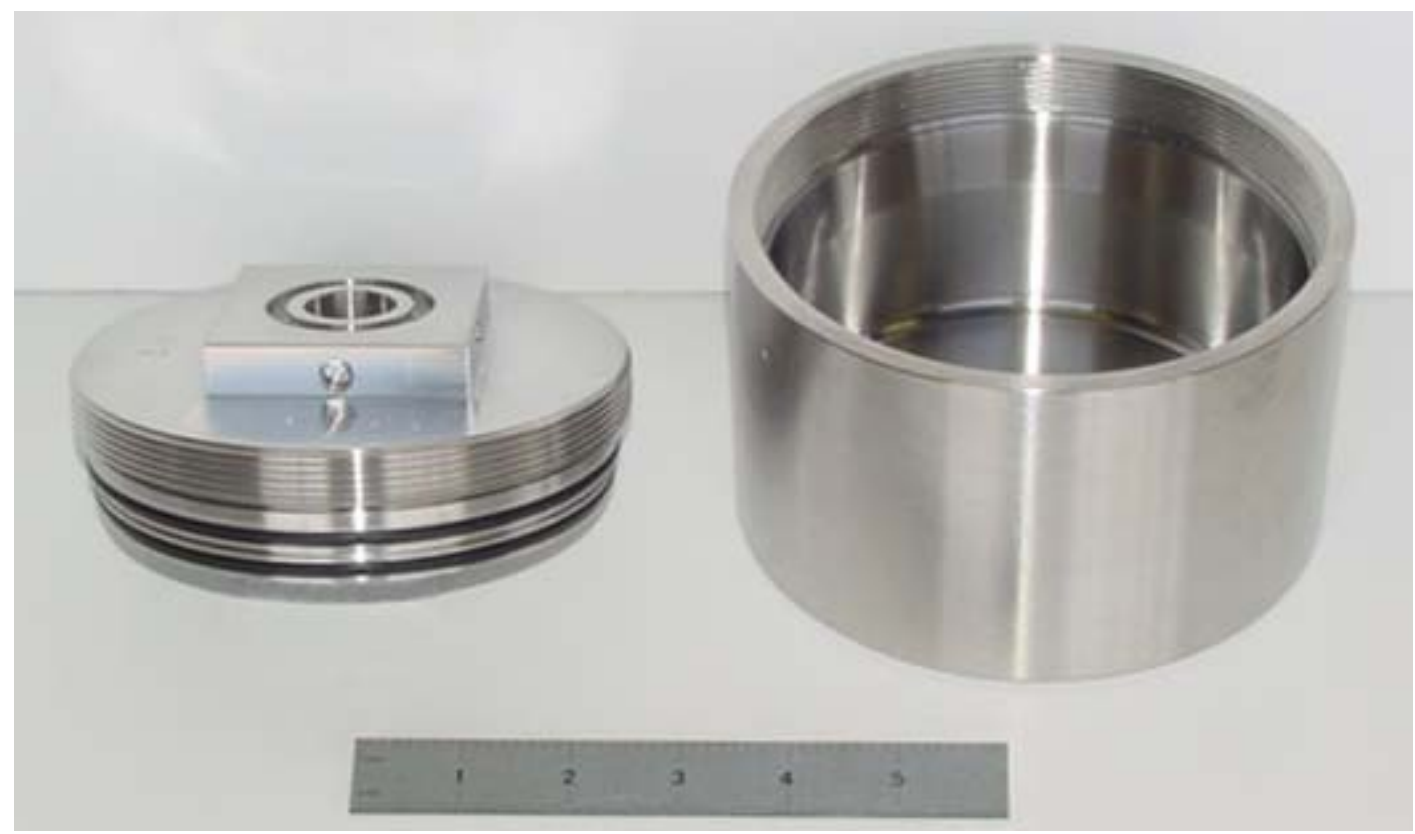

Figure 1. Mock-up PCV test fixture lid and body.

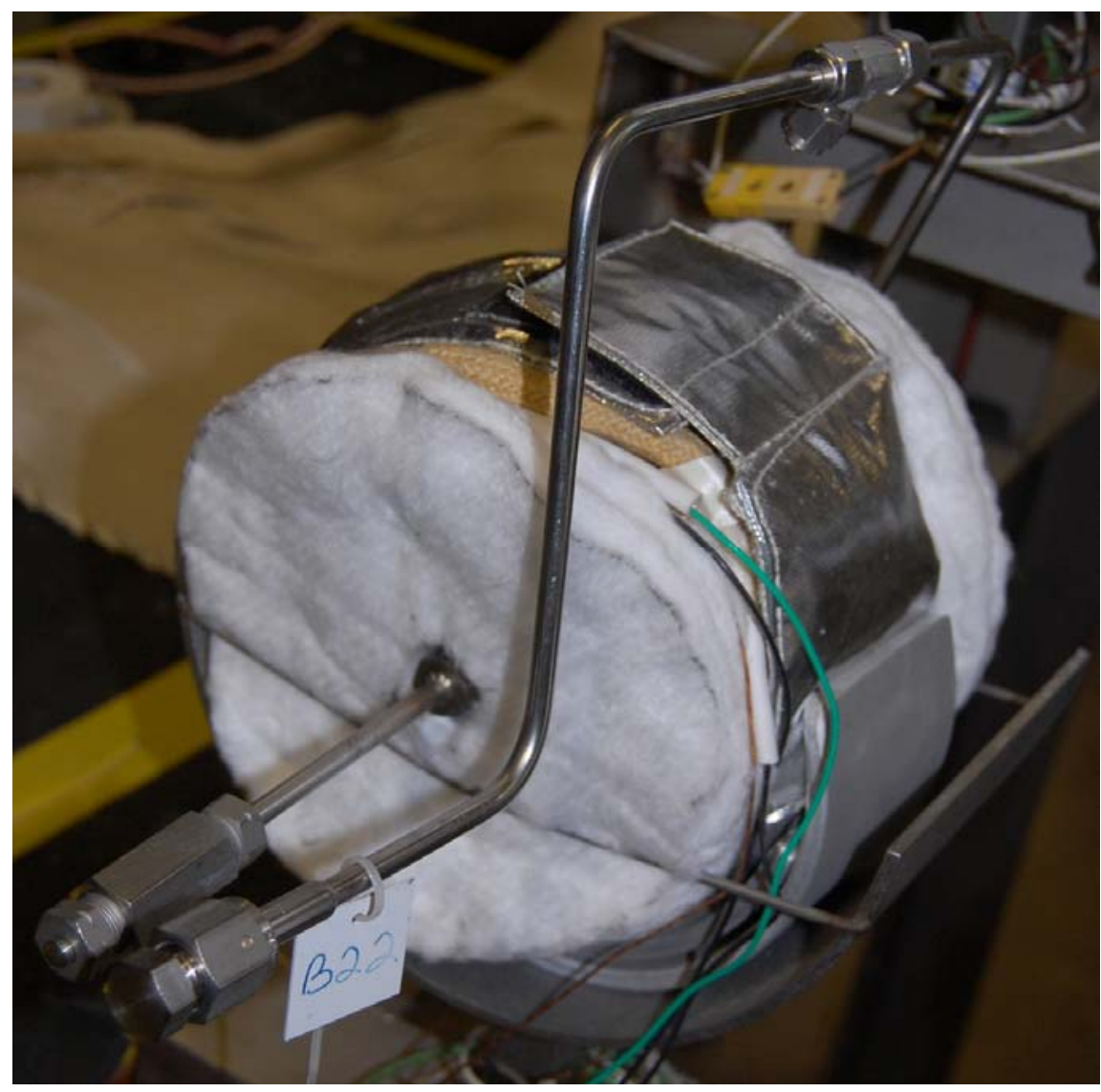

Figure 2. Assembled mock-up PCV. 


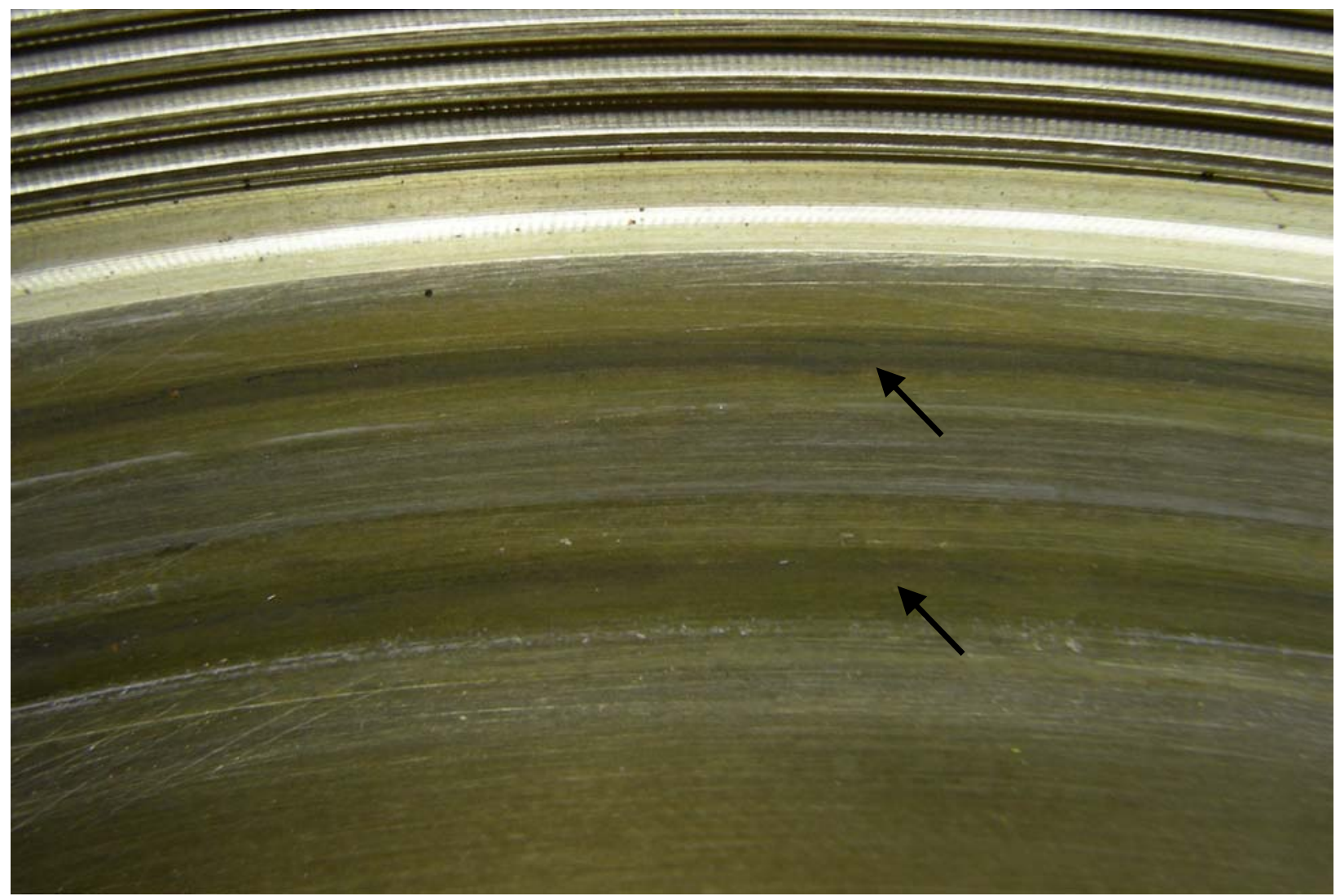

Figure 3. Black stain on the fixture 18D body from the O-rings.

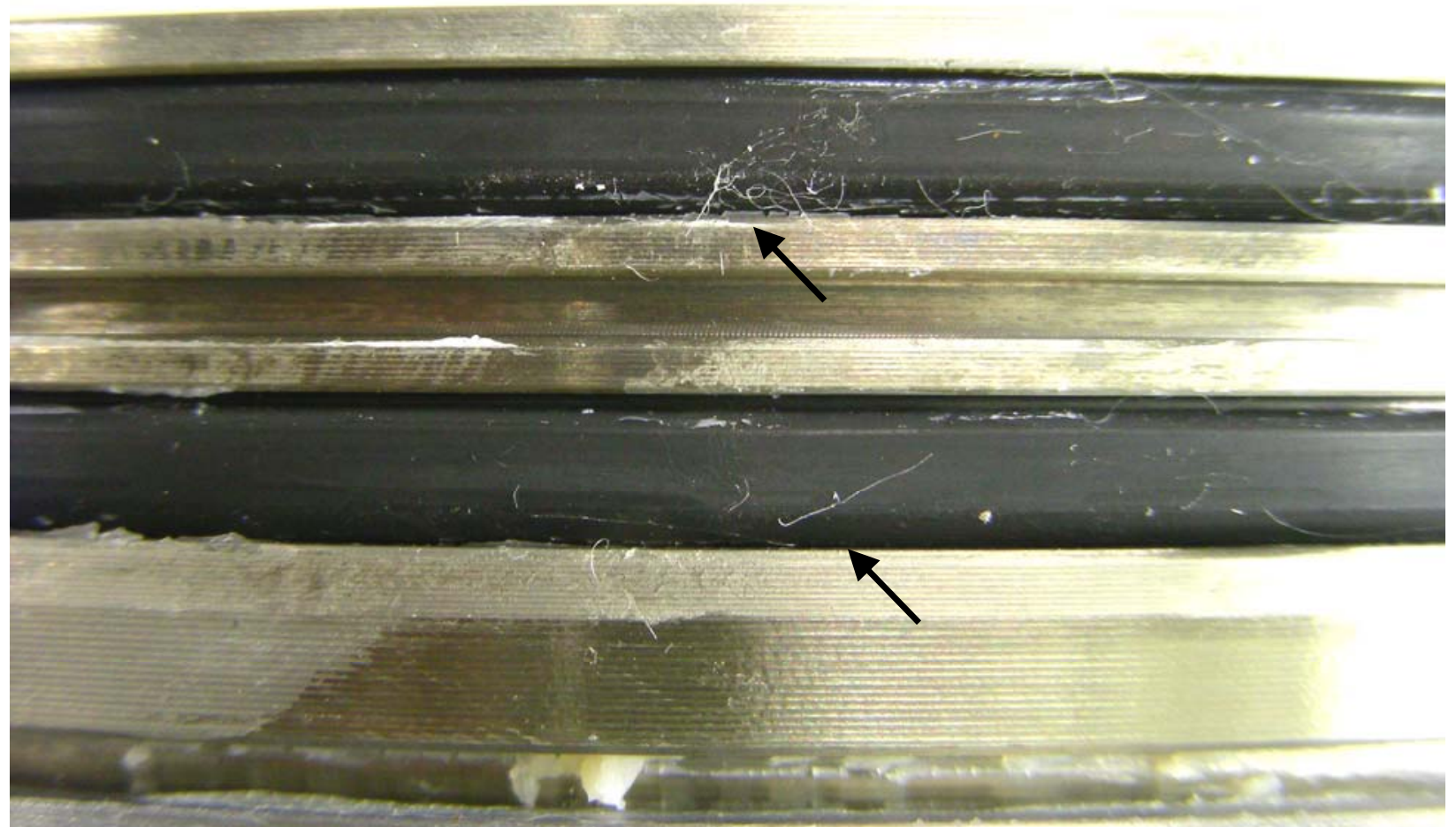

Figure 4. Fibers observed on the fixture 49 O-rings. 


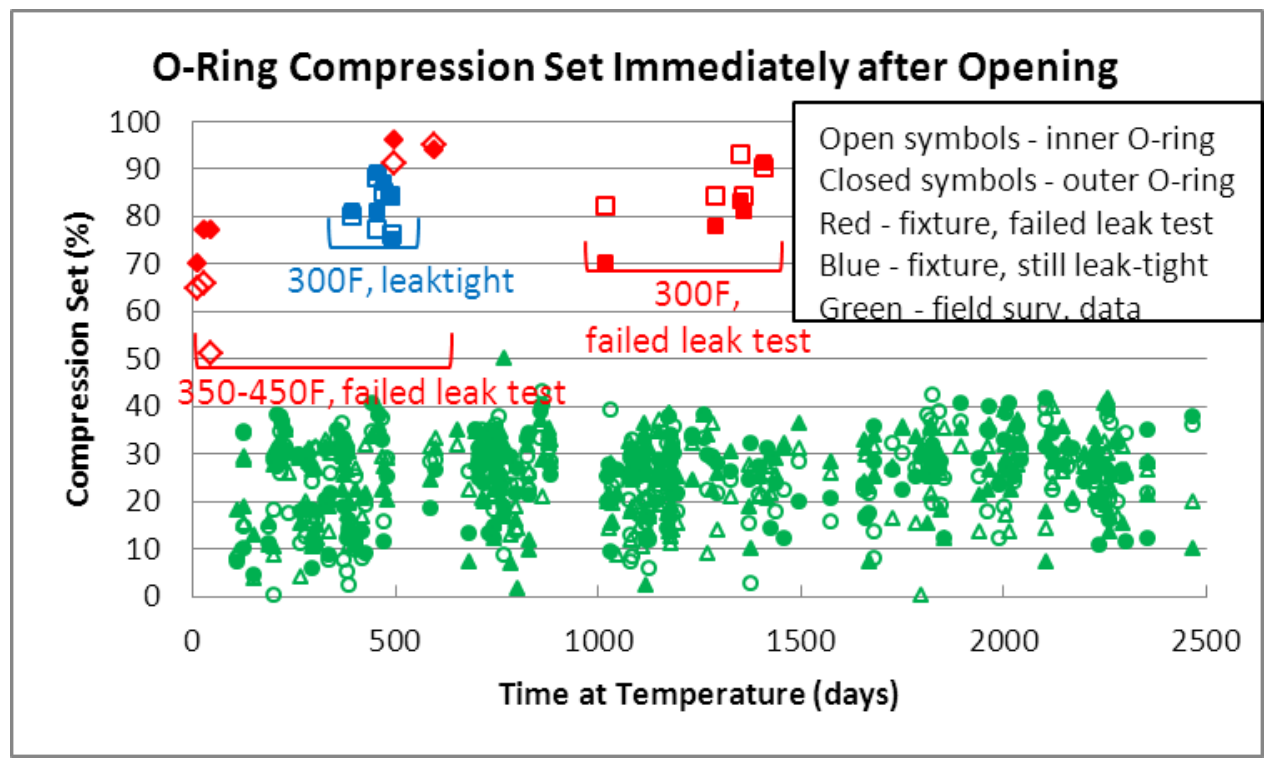

Figure 5. Compression set data for GLT O-rings based on measurements taken immediately after opening vessel (typically 30 minutes or less). The red symbols represent test fixtures aged at $300{ }^{\circ} \mathrm{F}$ or higher that failed to remain leaktight at room temperature. The blue symbols represent test fixtures aged at $300{ }^{\circ} \mathrm{F}$ removed from test due to difficulty with elevated temperature leak testing but remained leaktight at room temperature. The green symbols are from field surveillance PCV and SCV O-rings (presumed leaktight).

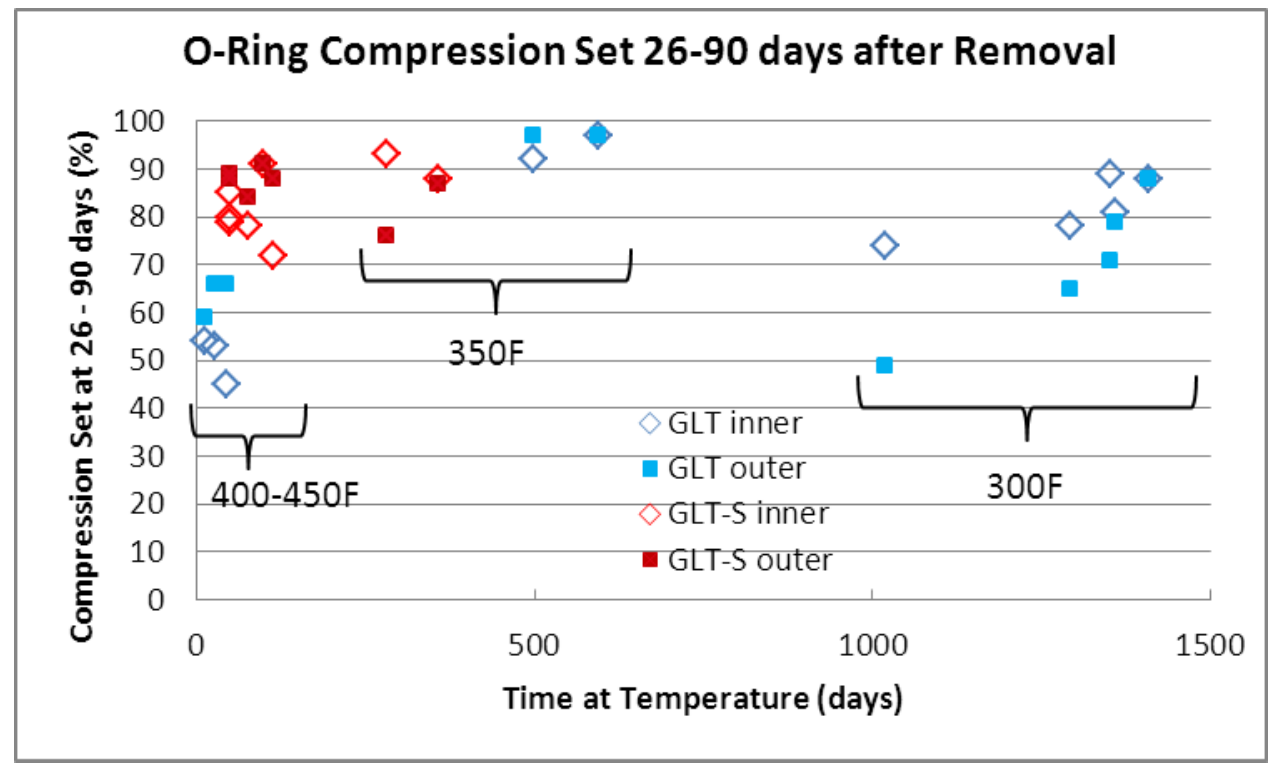

Figure 6. Compression set of GLT and GLT-S O-rings removed from test fixtures which failed to remain leaktight at room temperature. These results are based on remeasurements taken 26 - 90 days after opening the fixture. 


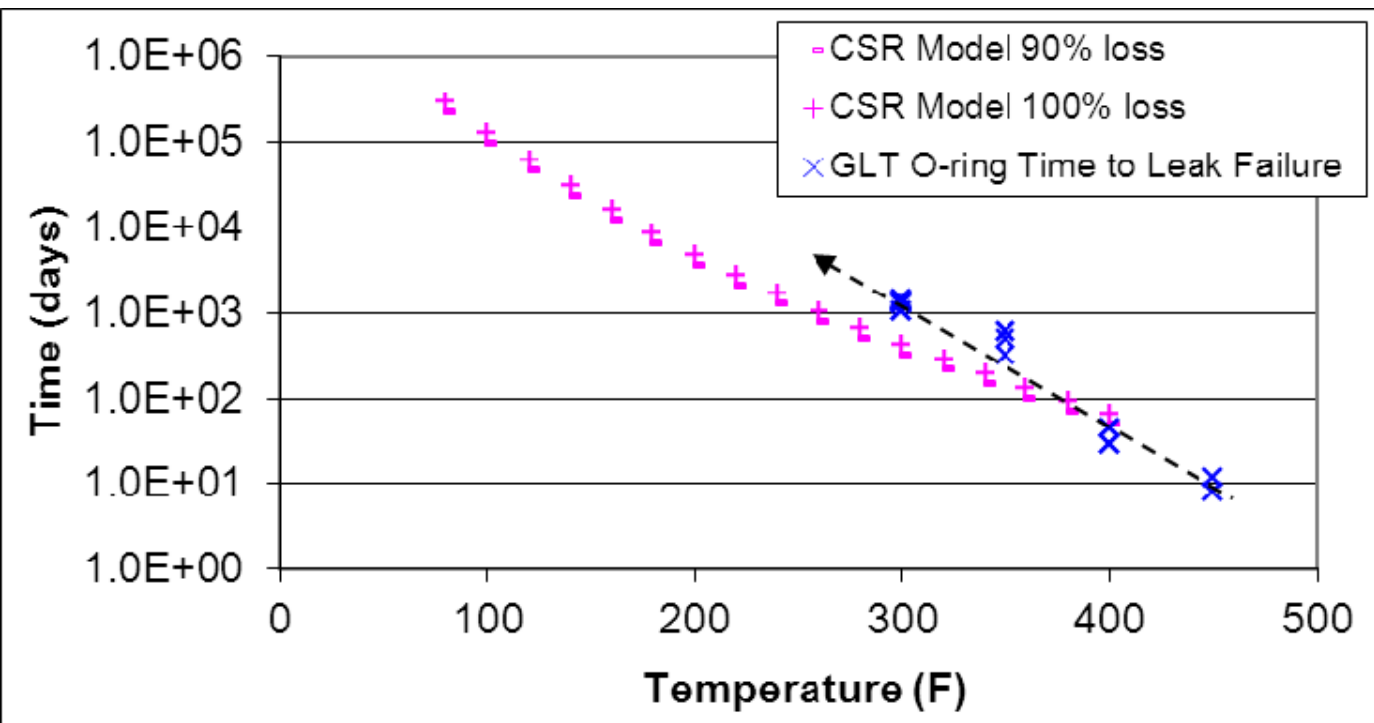

Figure 7 Leakage-based service life data for GLT O-rings (from fixtures with room temperature leak rate failures) compared to life predictions from GLT O-ring compression stress relaxation (CSR) data. 
CC: J. S. Bellamy, 773-41A

G. T. Chandler, 773-A

W. L. Daugherty, 773-A

K. A. Dunn, 773-41A

B. A. Eberhard, 105-K

E. R. Hackney, 705-K

M. K. Hackney, 705-K

E. N. Hoffman, 773-A

N. C. Iyer, 773-41A

D. R. Leduc, 773-41A

J. W. McClard, 705-K

J. W. McEvoy, 730-4B

D. L. Melvin, 705-K

T. M. Monahon, 705-K

T. E. Skidmore, 730-A

A. J. Stapf, 717-K

Document Control 